\title{
ENFORCING COVENANTS NOT TO COMPETE: THE LIFE-CYCLE IMPACT ON NEW FIRMS ${ }^{*}$
}

\author{
by \\ Evan Starr ${ }^{\ddagger}$ \\ University of Michigan
}

Natarajan Balasubramanian
Syracuse University

Mariko Sakakibara

University of California, Los Angeles

\section{CES 14-27 June, 2014}

The research program of the Center for Economic Studies (CES) produces a wide range of economic analyses to improve the statistical programs of the U.S. Census Bureau. Many of these analyses take the form of CES research papers. The papers have not undergone the review accorded Census Bureau publications and no endorsement should be inferred. Any opinions and conclusions expressed herein are those of the author(s) and do not necessarily represent the views of the U.S. Census Bureau. All results have been reviewed to ensure that no confidential information is disclosed. Republication in whole or part must be cleared with the authors.

To obtain information about the series, see www.census.gov/ces or contact Fariha Kamal, Editor, Discussion Papers, U.S. Census Bureau, Center for Economic Studies 2K132B, 4600 Silver Hill Road, Washington, DC 20233, CES.Papers.List@census.gov. 


\begin{abstract}
We examine the impact of enforcing non-compete covenants (CNC) on the formation and performance of new firms using matched employer-employee data on 30 US states. To identify the impact of CNC, we exploit the inter-state variation in CNC enforcement along with the fact that courts do not enforce such covenants between law firms and departing lawyers in any state. Using a difference-in-difference-in-difference specification with law firms and firms that are not withinindustry spinouts as the baseline, we find states with stricter CNC enforcement have fewer, but larger within-industry spinouts that are more likely to survive their nascent years, and conditional on survival, grow faster during those years. These results are consistent with CNC enforcement having a selection effect on within-industry spinouts. Particularly, with stricter enforcement, only founders with higher-quality ideas and resources choose to overcome CNCrelated barriers, which reduces entry rate but increases observed short-term performance of these spinouts.
\end{abstract}

Keyword: Covenants Not to Compete, Entrepreneurship, Spinouts

JEL Classification: L25, L26, L41, L5, K2, K3, J6, M2, M5

\footnotetext{
* Disclaimer: Any opinions and conclusions expressed herein are those of the authors and do not necessarily represent the views of the U.S. Census Bureau. All results have been reviewed to ensure that no confidential information is disclosed. This research uses data from the Census Bureau's Longitudinal Employer Household Dynamics Program, which was partially supported by the following National Science Foundation Grants SES9978093, SES-0339191 and ITR-0427889; National Institute on Aging Grant AG018854; and grants from the Alfred P. Sloan Foundation.

${ }^{\dagger}$ We would like to thank David Hsu, Mark Garmaise, Marvin Lieberman, Michael Darby, Steve Lippman, Lori Rosenkopf, Charlie Brown, Je rey Smith, Norman Bishara, JJ Prescott, and seminar participants at Wharton, UCLA, and the Census Bureau 2013 Research Data Center Annual Conference at the Atlanta Federal Reserve Bank for helpful comments. We are also grateful to the Kau man Foundation, the Harold Price Center for Entrepreneurial Studies at UCLA Anderson School of Management and the Academic Senate of the University of California, Los Angeles for supporting this work

${ }^{\ddagger}$ University of Michigan, Department of Economics, E-mail: starre@umich.edu

§ Syracuse University, Whitman School of Management, E-mail: nabalasu@syr.edu

『University of California, LosAngeles, Anderson School of Management, E-mail: mariko.sakakibara@anderson.ucla.edu
} 


\section{INTRODUCTION}

'Noncompete agreements...can be a significant impediment to people who aspire to start their own firms...'

-Rami Essaid, entrepreneur, in The Wall Street Journal, Aug 14, 2013

The creation of new firms and their subsequent performance are important concerns to researchers, entrepreneurs and policy makers. An important avenue of new firm formation is through employees of an existing firm leaving their employment to establish a new firm, sometimes referred to as a 'spinout'. Spinouts are of special interest because they have been known to perform better than other types of new firms (Agarwal et al. 2004; Klepper 2007; Chatterji, 2008; Klepper 2009), likely due to human capital that the founders developed at their previous employers. However, founders of spinouts are contractually bound to their prior employers via covenants not to compete $(\mathrm{CNC})$, which place constraints on the employee's post-separation freedom. In particular, by signing these agreements, employees are contractually prohibited from joining or establishing a competing firm for a specified period of time, within a stipulated geographic area.

While CNC are commonplace in all US states, there are significant inter-state variations in the degree of CNC enforcement. For example, while such agreements are void in California (Cal. Bus. \& Prof. Code $§ 16600)$, Florida permits the enforcement of CNC even when the employee is fired (F.S. §542.335). Naturally, the use of CNC and the degree to which they are enforced are likely to influence the decision of individuals to engage in entrepreneurial activity, especially when the new firms are formed as spinouts and become direct competitors to their parent firms. Fearing possible litigation from employers, potential spinout founders might be discouraged to leave their parent firms (Samila and Sorenson, 2011; Marx, 2011). In line with this argument, Samila and Sorenson (2011) found that CNC enforcement inhibits new firm formation. Similarly, Marx et al. (2009, 2011), Garmaise (2011) and Fallick et al. (2006) respectively found a link between CNC enforcement and the mobility of inventors, CEOs, and workers in California's IT cluster.

These studies show that CNC enforcement influences the entry of new firms and the mobility

of employees in certain occupations; however, we have no empirical evidence on the impact of CNC 
enforcement on new firms beyond their entry. ${ }^{1}$ In particular, it is likely that CNC enforcement affects not only the entry rate of new firms, but also their size, growth, and survival. Murphy et al. (1991) argue that when people are free to choose, they select occupations that offer the highest return on their abilities. If CNC enforcement acts as an entry barrier, then only founders with highquality ideas and resources - e.g., higher human capital, bigger networks, greater financial resources etc. - will risk the cost of potential CNC related lawsuits and establish direct competitors to their parent firms. Hence, those spinouts that do eventually form in states with strict $\mathrm{CNC}$ enforcement are likely to be of higher quality, broadly defined, and hence, have a larger initial size (Cooper et al, 1989).

Further, to the extent that initial idea quality and founder characteristics positively influence growth and survival in the nascent years (Santarelli and Vivarelli, 2007), such spinouts will also exhibit faster growth and higher survival during the first few years of their life. CNC enforcement also has other direct and indirect effects on new firm growth and survival. By making it harder to hire talented employees who are also bound by enforceable CNC, stricter CNC enforcement inhibits the growth of new firms and decreases their chances of survival. On the other hand, by limiting employee mobility, CNC enforcement may indirectly promote growth by preventing the dissemination of valuable knowledge and incentivizing firms to invest in growth-enhancing activities such as research and development.

Besides the limited focus on entry, there are two other gaps in our understanding of these important economic processes. First, to our knowledge, there are no firm-level studies on this question. While Marx et al. (2009) use inventor level analyses, Samila and Sorenson (2011) focus on aggregate new firm formation at the MSA level, identifying the relative impact of CNC enforcement through the amount of new venture capital in the region. Though such aggregate-level analysis provides very useful insights, more fine-grained firm-level analyses have the ability to inform us about the formation and development of entrepreneurial firms more directly. More importantly, the absence of a firm-level treatment implies that prior studies treat all new firms uniformly even though CNC enforcement will likely have a disparate impact depending on the type of new firm.

\footnotetext{
${ }^{1}$ Franco and Mitchell (2008) provide a theoretical model regarding the effect of CNC on spinout formation with a focus on regional dynamics.
} 
In particular, incumbent firms are more likely to litigate $\mathrm{CNC}$ against new firms formed by their employees if those new firms compete with them; other new firms are less likely to attract such litigation.

In this study, we use matched employer-employee data from 1990 to 2008 to analyze the formation and performance of about 5.5 million new firms from 30 US states covering all industries. In line with the above arguments on spinouts, we identify and pay special attention to 'withinindustry spinouts' - new firms established by employees leaving an incumbent firm and in the same NAICS 4-digit industry as the incumbent firm. Our baseline index of CNC enforcement is the index developed in Starr (2014), which utilizes factor analysis to re-weight seven observed dimensions of CNC enforcement initially quantified for the year 1991 by Bishara (2011). Compared to indices used in past studies, this index captures CNC enforcement with finer granularity along a spectrum of weak to strong enforcement.

Because CNC enforcement is enacted by state legislatures and state courts, who may be influenced by either pro-firm, pro-worker, or other interests of the state, it is a major empirical challenge to separate the impact of CNC enforcement on new firms from the myriad of other statelevel factors that may be correlated with $\mathrm{CNC}$ enforcement. Unable to use the natural experiments exploited in Marx et al. (2009), Conti (2013), and Garmaise (2011) because of the time span of our data and strict disclosure requirements for the matched employer-employee data, we develop a novel within-state difference-in-differences (DID) identification strategy. We divide firms into those that are affected by CNC enforcement (the treatment group) and those that are not (the control group). To the extent that the control group is equally affected by other state-level factors as the treatment group, the within-state difference in firm-level outcomes between the treatment and control group removes the effect of all other confounding state-level factors except for CNC enforcement.

To identify such a control group, we exploit an unusual aspect of law firms that is uniform across states: courts do not enforce any CNC between them and departing lawyers. The per se prohibition on CNC for lawyers was first suggested by the American Bar Association in 1961 and later codified in 1983 as Rule 5.6 of the Model Rules of Professional Conduct (Buffkin 1999). The prohibition has been adopted in every state in the US (Malsberger 1996, 2007), and hence, provides 
a natural control group to analyze the effect of $\mathrm{CNC}$ enforcement. The reliability of using law firms as a control group hinges upon the extent to which they accurately represent the counterfactual outcomes for non-law firms in the absence of CNC enforcement. While there are many reasons why firm-level outcomes for lawyers may not accurately reflect this counterfactual, such as the possibility that law firms actually enforce CNC, we argue that any bias resulting from the comparison between law and non-law firms is likely to bias our estimates toward zero.

We then identify differential effects for within-industry spinouts, by taking a difference-indifference-in-difference (DIDID) approach, in which we contrast within-industry spinouts to other new firms in the same NAICS 4-digit industry-year in the same state. Thus we compare how the difference between within-industry non-law spinouts and other new non-law firms (first difference) and the corresponding difference between within-industry law spinouts and other new law firms (second difference) varies with the degree of CNC enforcement (third difference). Put differently, we compare how $\left[Y_{W S O}-Y_{\text {Other }}\right]_{\text {Non law }}-\left[Y_{W S O}-Y_{\text {Other }}\right]_{\text {Law }}$ changes with CNC enforcement, where $Y$ is the outcome of interest and WSO refers to within-industry spinouts. Importantly, using three differences eliminates the impact of factors common to within-industry spinouts and other firms in the same industry-year, and addresses the possibility that unobserved variables unique to law firms and correlated with $\mathrm{CNC}$ enforcement are biasing the results.

Based on these DIDID analyses, we find that the rate of entry of within-industry spinouts is negatively correlated with CNC enforcement. However, the within-industry spinouts that are established tend to be larger, faster growing relative to other new firms, and more likely to survive the first few years. In particular, our specifications indicate that a unit increase in the enforcement index is associated with about a 0.13 percentage-point decrease in entry rate of within-industry spinouts, a $1.1 \%$ increase in initial employment among within-industry spinouts, and a 0.12 percentage-point higher probability of surviving the first year. Conditional on survival and initial size, a unit increase in the enforcement index is also associated with a $0.42 \%$ increase in employment in the first 3 years of their life. However, these effects largely seem to be limited to the first few years, and disappear over the long-term. Controlling for initial size, we find almost no difference in survival probabilities and no size or growth difference after three years. ${ }^{2}$

\footnotetext{
${ }^{2}$ In contrast, based on the DID specification, we find that CNC enforcement has no effect on the entry rate or
} 
These results are consistent with CNC enforcement having a selection effect on within-industry spinouts. The fact that the inclusion of initial size as a control in the future size and survival regressions significantly mitigates the impact of $\mathrm{CNC}$ enforcement suggests that the impact of stricter enforcement on within-industry spinouts is through its effect on initial size, a variable very likely to be influenced by selection. Additionally, we find that CNC enforcement is associated with higher earnings of founders prior to spinout formation, suggesting that founders with lower human capital are less likely to form within-industry spinouts in the presence of strict enforcement. Consistent with selection, we also find that within-industry spinouts tend to have smaller parents in high enforcement states. Our results are robust to alternative specifications using professional services firms and technology firms as treatment groups and to alternative measures of CNC enforcement including the 1992 and 2002 indices in Garmaise (2011).

Together, our results make two substantive contributions to the literature on new firms. First, we show that CNC not only have an influence on the entry but also the size, growth and survival of (some types of) new firms. Thus, our study enables a significantly more comprehensive assessment of the effect of CNC enforcement. Second, our study is the first to demonstrate that such covenants have a heterogeneous effect depending on the type of new firm. By doing so, we hope to improve our understanding of the mechanisms that link CNC enforcement to new firm formation and performance. In addition to these, by highlighting the unique role of spinouts, our study also contributes to the broader literature on spinouts (e.g., Agarwal, 2004; Klepper, 2001, 2007; Klepper and Sleeper, 2005; Campbell et al., 2012) by shedding light on how a particular policy instrument affects the process of spinout formation.

The rest of the paper is organized as follows. Section II provides details on CNC and related legal processes, and presents the potential effects of CNC enforcement on the life cycle of new firms. The data and empirical methodology are described in Section III, and the results are presented in Section IV. Section V discusses and concludes.

growth of all new non-law firms, only a weak negative effect on their initial size and a slightly stronger negative effect on their probability of survival in the first few years. 


\section{Covenants Not to Compete}

\section{CNC and CNC Enforcement}

Covenants not to compete are post-employment restraints which prohibit employees from either joining competitors or starting a competing firm for a specified amount of time (typically one to two years (Gilson, 1999)) and in a specified geographic region. Since the departure of employees can disseminate proprietary knowledge or technology, both valuable sources of competitive advantage (Barney, 1991; Grant, 1996), firms use CNC to protect trade secrets, client lists, and other intangible assets. CNC appear in contracts for all types of workers, ranging from CEOs to minimum wage workers. Indeed, legal scholars believe them to be commonplace in employment contracts (Stone, 2002).

The degree of CNC enforcement varies considerably among states, and often depends upon the process by which the CNC was signed and potentially violated. Once a firm decides to take a former employee to court over a potential violation of the employee's CNC, judges are bound by either state statute or state precedents in case law. ${ }^{3}$ Most states enforce CNC according to some version of the "Rule of Reason," which was initially developed in 1711 in England. The "Rule of Reason" balances the protection needed by the firm with the harm done to the employee and society (Blake, 1960). A necessary condition for the enforcement of CNC in any state is that the employee possesses trade secrets, access to clients or client lists, or other types of confidential information which gain value from not being publicly known. Some states will also enforce CNC on the basis of extraordinary training expenses. Given the possession of some kind of protectable interest, states exhibit significant variation in the circumstances under which they consider a CNC enforceable. As alluded to in the Introduction, California and Florida have considerable differences with respect to CNC enforcement. There are significant differences in other states as well. For example, while many states handle unreasonably overbroad contracts by modifying them to be reasonable and

\footnotetext{
${ }^{3}$ Alternatively, employees who move to a state less likely to enforce a CNC may file suit in that state in an attempt to have their CNC annulled. Simultaneously, their former employer may file suit in the state where the employee formerly worked. In this complicated situation, there is sometimes a race to the decision, where the slower state can choose to abide by the other state's judgement. Each state, however, does not necessarily have to abide by the judgement of another state. See Advanced Bionics Corp. v. Medtronic, Inc. 59 P.3d 231, 238 (California 2002) for a complex case and Glynn (2008) for more on choices of forum, law, and interjurisdictional issues. Also, note that we limit our analysis to within-industry spinouts formed in the same state as parent firms.
} 
subsequently enforcing them, Wisconsin does not allow such "blue penciling" and voids the entire contract if any part is overbroad. In other states, such as Oregon, enforceable CNC require that some kind of additional consideration beyond continued employment be given to the employee in exchange for signing. These and other dimensions of enforcement are discussed for each state in the Malsberger series Covenants Not to Compete: A State by State Survey.

\section{Effects of CNC Enforcement on New Firms}

By binding employees and their knowledge to one firm, the ubiquitous use of CNC in employment contracts has direct and indirect consequences for both the creation of new firms and their subsequent growth and survival. The direct effects involve CNC's role as entry and hiring barriers for new firms, while the indirect effects relate to $\mathrm{CNC}$ encouraging firms to invest in intangible assets such as research and development and human capital.

Directly, CNC impose exit barriers on workers who wish to leave their current employers and apply their skills outside (Marx, 2011). CNC provide parent firms with an option to take legal action against the workers. In fact, lawsuits for breach of CNC have become common and are among the most frequently litigated issues in employment law (Stone, 2002). This potential litigation acts as an entry barrier or an additional cost to entrepreneurs who wish to start a spinout that competes with their parent firm. Specifically, stricter CNC enforcement increases the likelihood that parent firms file a lawsuit against the founders for violating CNC. Consequently, this not only entails additional litigation costs for the new firm but also may cause it to fail if the lawsuit is decided in favor of the parent firm. Rauch and Watson (2014), for example, model this kind of cost as monetary transfer from an employee to the firm to buy out his/her CNC contract and start a new firm. Given this additional cost, only employees who identify very good business opportunities or are endowed with better resources are willing to pay the potential costs of future lawsuits.

This additional cost also affects both the observed entry and initial size of within-industry spinouts. As Cooper et al. (1989) and other subsequent studies have found, the initial size of new firms is positively correlated with the human capital of founders including their education and work experience, which enables them to assemble more and better resources for their venture. Similarly, within a given entry cohort in an industry, one can expect a positive correlation between the quality 
of the initial idea and the initial size. Then, assuming that the distribution of quality of founders' ideas and resources is the same across states for a given industry-year, stricter enforcement of CNC reduces the number of new within-industry spinouts by making it harder for founders with lowerquality ideas and resources to enter. This also implies that fewer small new firms will be created in states with stricter enforcement, and that the observed average initial size of within-industry spinouts will be higher in such states. New firms that do not compete with their parent firm do not face this additional cost and their creation will not be affected by $\mathrm{CNC}$ enforcement.

In addition, the possibility of CNC-related litigation also acts as a hiring barrier for firms. This only adds to the entry barriers arising from potential CNC litigation faced by the founders of within-industry spinouts. As a result, potential founders of such spin-outs may vet their ideas more thoroughly, particularly to ensure that others are willing to join them if they decide to start the firm. This further strengthens the selection argument. Founders of other new firms may also consider the hiring constraints of $\mathrm{CNC}$ enforcement to be a barrier, but because they risk no litigation from an incumbent firm related to their entry, the additional barriers related to hiring restrictions are likely to be mitigated.

The second direct effect of stricter CNC enforcement is reduced mobility of employees who now face a greater likelihood of CNC-related litigation. This reduced mobility of employees impacts the growth of new firms, irrespective of whether they are within-industry spinouts or not, because growth depends upon the ability of the new firm to attract talented employees, which can be limited if those employees are also bound by enforceable CNC. After all, like the founders, employees are not likely to join a firm at which their expected costs, including potential CNC litigation from their parent firm, exceed their expected utility from joining the new firm. Further, this hiring barrier might affect the recruiting of new firms to a greater extent than incumbent firms. Prospective recruits may more willingly join a firm with uncertain survival prospects when they believe that they can easily find a new job should the new firm fail. In regions in which CNC is enforced, they might face greater difficulty in finding a new job due to limited mobility and limited development of a social network which they can draw on (Stuart and Sorenson, 2003). Also, due to the legal system's asymmetric costs for small firms (Lerner, 1995), individuals who wish to change jobs may be more likely to join large firms that can credibly promise to defend them against a lawsuit from 
their former employers, making it difficult for startups to attract talent (Marx, 2011). Consequently, new firms in stricter enforcing states will grow slower, conditional on initial size. The hiring barriers imposed by CNC enforcement might also reduce the chances of survival of new firms because they might not be able to build the human capital necessary to effectively defend their initial business ideas against competitive responses by incumbent firms and other startups.

CNC enforcement also has indirect effects on firm behavior, particularly through its effect on employee mobility. By allowing firms to better appropriate the gains from their investments, a reduction in employee mobility to competitors generally increases the incentives for firms to invest in human capital through training (Meccheri, 2009; Starr, 2014), research and development and intra-firm information sharing (Grossman and Hart, 1986; Hart and Moore, 1990; Garmaise, 2011; Starr, 2014). In particular, if employees can move freely to a firm's competitors, the firm may not be willing to invest in building transferable skills (and knowledge) that are valuable to competitors (e.g., industry-specific expertise). Similarly, they may be less willing to share sensitive information that may be valuable to competitors or may hurt the firm if that information were leaked to competitors. In contrast, $\mathrm{CNC}$ enforcement gives employers property rights over the tacit knowledge embodied in employees (Gilson, 1999), restoring incentives to invest in human capital.

In line with these arguments, Starr (2014) shows empirically that firms in stricter enforcing states are more likely to provide skill-upgrading training to their employees. ${ }^{4}$ Similarly, Conti (2013) finds that incumbent firms in stricter enforcing states are willing to pursue riskier R\&D strategies because stricter enforcement is more likely to reduce the leakages of the payoffs from high-risk $R \& D$ projects. The impact of such increases in human capital and R\&D investment and intra-firm information sharing may open up high-quality business opportunities that would not have otherwise existed. This indirect effect, in turn, increases the initial size of new firms by improving the quality of new business ideas and founder human capital, and also enables the new firm to grow faster by making these types of investments. Similarly, by allowing new firms to build knowledge capital, CNC enforcement might increase the chance of survival of new firms. ${ }^{5}$

\footnotetext{
${ }^{4}$ Garmaise (2011) argues that stricter CNC enforcement reduces incentives for managers to invest in their own human capital. However, it is not clear how investment by managers in their own, transferable human capital will translate into firm growth.

${ }^{5}$ Reduced mobility may also impede R\&D investments and consequently growth, by not only limiting the development of firm absorptive capacity but also of an industry-wide spillover pool from which firms can draw ideas
} 
To summarize, these arguments suggest that CNC serve as an entry barrier and a hiring barrier for within-industry spinouts. Thus, by raising the threshold to enter the market, stricter $\mathrm{CNC}$ enforcement will reduce the entry rate of within-industry spinouts relative to other new firms but will be associated with an increase in the initial size of within-industry spinouts. CNC's role as a hiring barrier limits the growth of new firms, but CNC enforcement encourages new firms to invest in human capital, which leads to their growth. This conflicting role of CNC on new firm growth affects the survival of new firms in a similar manner. Therefore, the effect on growth and survival of new firms is theoretically ambiguous.

\section{DATA AND EMPIRICS}

The data for the study come from two micro-level datasets at the U.S. Census Bureau: the 'Longitudinal Business Database' (LBD) and the 'Longitudinal Employer Household Dynamics' (LEHD). The LBD is the universe of all establishments in the US that have at least one employee. $^{6}$ For each year from 1976 to 2010, this dataset contains information on employment at the establishment in addition to data on the industry, geography and corporate ownership of the establishment. It does not contain information on revenues or on any other expenditure.

The LEHD is a composite matched employer-employee dataset comprising multiple statelevel databases. The two relevant databases within the LEHD are (a) the 'Employment History File' (EHF), which provides the employment history of all individuals that work in establishments in states that participate in this program, and (b) the 'Employer Characteristics File' (ECF) which contains information on all employers (i.e. establishments) in states that participate in this program. These databases, maintained separately for each participating state, contain quarterly information on employment and payroll for the establishment, and wage information for the individual. In particular, for each individual, for each quarter, the database provides the payroll they obtained from each firm they worked for (identified by the 'State Employer Identification Number' or the SEIN).

(Fosfuri and Ronde, 2004). This may be particularly relevant when combining knowledge across firms is important. However, employees switching jobs is only one of many possible spillover mechanisms, and it is not clear why formal knowledge-sharing mechanisms between firms may not achieve the same objectives. Reduced mobility may also potentially decrease employee human capital by reducing the experience they gain by working at multiple firms.

${ }^{6}$ An establishment is defined as 'An establishment is a single physical location at which business is conducted and/or services are provided' (http://www.census.gov/econ/susb/definitions.html, retrieved Sep 24, 2013). If very distinct activities are performed at a location, then they are classified as separate establishments. 
Like the LBD, the LEHD does not contain information on revenues or on any other expenditure. The first year the LEHD data are available for at least three states is 1990. The geographical coverage of the data increases over time as more states begin to participate in this program. Our study was based on 30 states. $^{7}$

To obtain the list of new firms from the LBD, we selected all establishments that were born in the states and during the years for which we had data from the LEHD. We then excluded establishments belonging to multi-unit firms or to firms that were started more than 1 year prior to the start of the establishment. This sample, which represents almost all new employers in the LEHD-relevant states and years, consisted of about 5.5 million firms which were formed between 1990 and 2008. We then identified a subset of these new firms as within-industry spinouts, the details of which are provided below.

\section{Identifying within-industry spinouts}

We identified within-industry spinouts based on employee-movement data from the LEHD. We began by identifying 'clusters' of one or more employees moving from one establishment ('the predecessor establishment') to another ('the successor establishment') within the same state during a 1-year period. ${ }^{8}$ We chose 1 -year as many CNC last for 1 year. Of these clusters, we restricted our attention to clusters that had less than 20 employees as potential spinouts. The reasoning for this criterion was that clusters with large numbers of employees are more likely to be data errors or administrative problems such as name changes rather than true spinouts. From these clusters, we excluded clusters where the predecessor establishment was too small relative to cluster size; specifically, we imposed a condition that the cluster size be at most $50 \%$ of employment at the predecessor establishment. We also excluded clusters where the successor establishment was too large relative to cluster size; specifically, we imposed a condition that the cluster size be at least $75 \%$ of employment at the successor establishment. These conditions were aimed at reducing the likelihood of simple ownership changes being identified as spinouts. We also excluded clusters where

\footnotetext{
${ }^{7}$ The states included in our LEHD data are Arkansas, California, Colorado, Florida, Georgia, Hawaii, Iowa, Idaho, Illinois, Indiana, Louisiana, Maryland, Maine, Montana, North Carolina, New Jersey, New Mexico, Nevada, Oklahoma, Oregon, Rhode Island, South Carolina, Tennessee, Texas, Utah, Virginia, Vermont, Washington, Wisconsin, and West Virginia.

${ }^{8}$ We focus on spinouts formed in the same state as their parent because these spinouts are more likely to be litigated than out-of-state spinouts, and out-of-state spinouts are only a small fraction of all spinouts.
} 
the successor establishment was more than one year old at the time of the employees moving to the establishment. Broadly then, these clusters represent groups of employees moving from an existing firm to join a new firm.

This preliminary list was then refined by using data from the LBD to exclude SEINs owned by firms present in multiple states. From this list, we identified 'within-industry spinouts' as spinouts that have the same 4-digit NAICS code as their parent firm. About $8.4 \%$ of all new firms were classifed as within-industry spinouts. Additional descriptive statistics are provided in Table $1 .{ }^{9}$

\section{Measuring CNC Enforcement}

Malsberger's series Covenants Not to Compete: A State by State Survey tracks the case law for each state along numerous dimensions of enforcement including state statutes, what constitutes a protectable interest, the burden of proof on the plaintiff, handling of overbroad contracts, employee consideration, the manner of separation, and others. Bishara (2011) and Garmaise (2011) each quantify these various dimensions of enforcement. Bishara's index scores seven dimensions from zero to ten, while Garmaise gives a binary score to twelve dimensions. We use as a baseline the 1991 enforcement index developed in Starr (2014) which modifies the Bishara (2011) index by performing factor analysis to re-weight the seven dimensions of enforcement. ${ }^{10}$ The Starr-Bishara index has the advantage of removing the redundancy of the seven dimensions of enforcement and capturing a finer granularity of the way enforcement is construed along a spectrum of weak to strong enforcement. Table 2 from Starr (2014) reports the means for the seven dimensions of enforcement and the factor analysis weights, and Figure 1 presents the result enforcement scores by state for 1991 and 2009. ${ }^{11}$

The enforcement index, normalized to be mean 0 , standard deviation 1 , is a continuous measure which runs from -4 to 1.15. As Figure 1 shows, there is not much variation across time,

\footnotetext{
${ }^{9}$ Since industry is measured at the NAICS 4 digit level, it is likely that some of these within-industry spinouts are not competitors with their parent firms. The inclusion of non-competitors in within-industry spinouts biases the estimated effects of CNC enforcement towards zero.

${ }^{10} \mathrm{~A}$ similar procedure cannot be performed on the Garmaise index because factor analysis does not work with binary variables.

${ }^{11}$ The highly positive correlations between the underlying dimensions suggests that any re-weighting scheme produces highly correlated indices. Indeed, the correlation between the Starr-Bishara index and the initial Bishara (2011) index is 0.94 .
} 
but significant variation across states. ${ }^{12}$ Some states have introduced some small changes over time, such as Oregon's 2008 law that employers notify workers in advance of their CNC, but others have not changed their policies at all. California, for example, adopted their prohibition of CNC in 1872 (Gilson 1999) and has not touched it since.

\section{Identification}

The ideal setup to identify the impact of CNC enforcement on the creation and performance of new firms is one in which $\mathrm{CNC}$ enforcement is randomly determined for each state. Of course, CNC enforcement is not determined randomly, but instead by state legislatures and state judges who are potentially influenced by pro-firm, pro-worker, or other interests in their state. For example, California, one of the least enforcing states, was the first state to adopt the (pro-worker) public policy, good faith, and implied contract exceptions to at-will employment (Autor et al. 2006), while Florida, the highest CNC enforcing state, has not adopted any exceptions to at-will employment as of this writing (Morris 2013). As a result, CNC enforcement is likely to be correlated with many state level policies, and any purely cross-sectional comparison of new firm creation, growth, and survival across high and low enforcing states is likely to be seriously contaminated by omitted variables.

To address the nonrandom selection of CNC enforcement, other studies such as Marx et al. (2009), Garmaise (2011), and Conti (2013) treat CNC law changes in Michigan in 1985, Texas in 1994, Florida in 1996, and Louisiana in 2001 as natural experiments and perform a difference-indifference analysis before and after the changes. Due to the timespan of our data and restrictive disclosure requirements from the LEHD, we cannot pursue this longitudinal identification strategy. ${ }^{13}$

Instead, we use a novel identification strategy which relies on the fact that law firms constitute the only industry in which CNC enforcement is prohibited in every state. The primary argument for such a prohibition is that limiting a lawyer's ability to practice is equivalent to limiting a client's choice of attorney (Buffkin 1999, Stroud 2002). The American Bar Association (ABA) first wrote

\footnotetext{
${ }^{12}$ During our time period, only Louisiana had a significant reversal in its CNC laws but disclosure regulations prevent us from studying this reversal with restricted data. In all of our specifications we include a dummy for Louisiana between 2002 and 2003, which partials out this effect.

${ }^{13}$ To disclose any binary variable from the LEHD, it must contain at least 3 states on either side. Without a pre-period for Texas in the LEHD, there are only 2 states with longitudinal variation.
} 
in Formal Opinion 300 in 1961, then in Disciplinary Rule 2-108(A) in 1969, and finally codified in 1983 as Rule 5.6 of the ABA's Model Rules of Professional Conduct what has become a per se prohibition on the enforcement of covenants not to compete for lawyers (Buffkin 1999). Model Rule 5.6 states:

A lawyer shall not participate in offering or making:

(a) a partnership, shareholders, operating, employment, or other similar type of agreement that restricts the right of a lawyer to practice after termination of the relationship, except an agreement concerning benefits upon retirement; or

(b) an agreement in which a restriction on the lawyer's right to practice is part of the settlement of a client controversy.

Stroud (2002) writes, "Rule 5.6 effectively separated law firms from the group of professions included under the reasonableness analysis for covenants not to compete." The first challenge to this ban occurred in Dwyer v. Jung in 1975, wherein partners had signed an agreement such that upon dissolution of the practice the clients would be equally divided and each partner could not access another partner's clients for five years. The judge leaned on Disciplinary Rule 2-108(A) in his findings and invalidated the contracts, distinguishing between general restrictive covenants and those between lawyers. Courts have generally reaffirmed Dwyer though some have enforced other indirect components of contracts between lawyers such as retirement benefits ${ }^{14}$ and forfeiture of compensation clauses. ${ }^{15}$ Stroud (2002) reviews this development of case law.

Thus, to the extent that law firms are not affected by CNC enforcement but are just as affected by all non-CNC, state-level variables as non-law firms, law firms form a natural control group for identifying the treatment effect of CNC enforcement. This forms the basis of our DID identification strategy. The difference in firm-level outcomes between non-law and law firms within a state differences out confounding state-level correlates, leaving the effect of CNC enforcement. In other words, our DID approach examines how the within-state difference in creation, growth, and survival between non-law and law new firms varies by the CNC enforcement level of the state. ${ }^{16}$

\footnotetext{
${ }^{14}$ See Miller v. Foulston 790 P.2d 404 (Kan. 1990)

${ }^{15}$ See Haight. Brown \& Bonesteel v. Superior Court. 285 Cal. Rptr. 845, 846.

${ }^{16}$ This identification strategy is similar in spirit to both Samila and Sorenson (2011), who use venture capital as
} 
To identify the differential effect for within-industry spinouts from other types of new firms, we use DIDID or a triple difference framework. This framework examines how the difference between the difference of non-law within-industry spinouts and non-law non-within-industry spinouts (first difference) and the difference of law within-industry-spinouts and law non-within-industry-spinouts (second difference) varies with CNC enforcement (third difference). That is, we compare how $\left[Y_{W S O}-Y_{\text {Other }}\right]_{\text {Non law }}-\left[Y_{W S O}-Y_{\text {Other }}\right]_{\text {Law }}$ changes with CNC enforcement, where $Y$ is the outcome of interest and WSO refers to within-industry spinouts.

To examine the impact of enforcement on the creation of new firms, we aggregate the establishment level data to the state-year-industry level. The baseline creation specification is

$$
Y_{i s t}^{c}=\gamma_{1} N L_{i} * E n f c_{s}+\lambda_{i t}+\theta_{s}+\phi Z_{i j s t}+v_{i j s t}
$$

where $Y_{i s t}^{c}$ refers to the creation outcomes of interest: the entry rates of new firms, within-industry spinouts, and non-within-industry spinouts in state $s$ and industry $i$ at time $t$. Variable $N L_{i}$ refers to an industry $i$ being 'not law,' $E n f c_{s}$ refers to the state level CNC enforcement, $\lambda_{i t}$ are industryby-year fixed effects, $\theta_{s}$ are state fixed effects, and $Z_{i j s t}$ are other controls. ${ }^{17}$ The coefficient $\gamma_{1}$ represents the impact of a one standard deviation increase in $\mathrm{CNC}$ enforcement on the entry rate of new firms and within-industry spinouts relative to the impact on law firms.

To examine the impact of $\mathrm{CNC}$ enforcement on the size of new firms, and their employment growth and survival, we use the following DID specifications at the establishment level:

$$
\begin{gathered}
Y_{i j s t}=\alpha_{0}+\alpha_{1} N L_{i} * E n f c_{s}+\alpha_{2} W S O_{i j s t} * N L_{i}+\alpha_{3} W S O_{i j s t}+\lambda_{i t}+\theta_{s} \\
+\phi Z_{i j s t}+v_{i j s t} \\
Y_{i j s t}=\beta_{0}+\beta_{1} N L_{i} * E n f c_{s} * W S O_{i j s t}+\beta_{2} N L_{i} * E n f c_{s}+\beta_{3} E n f c_{s} * W S O \\
+\beta_{4} W S O_{i j s t} * N L_{i}+\beta_{5} W S O_{i j s t}+\lambda_{i t}+\theta_{s}+\phi Z_{i j s t}+v_{i j s t}
\end{gathered}
$$

where $Y_{i j s t}$ refers to the outcomes of interest, log employment at year $0,3,5$, and 7, and dummies the first difference, and Starr (2014), who uses litigiousness of occupations as the first difference.

${ }^{17}$ Entry rate here is defined as the number of new firms in a state-year-NAICS 4 digit industry divided by the total number of establishments in the state-year-NAICS 4 digit industry. 
for surviving 1, 2, and 3 years. The variable $W S O_{i j s t}$ refers to a dummy for firm $j$ being a withinindustry $i$ spinout at time $t$ in state $s$.

Specification (2) is the DID specification that examines the impact of CNC enforcement on law and non-law new firms, treating within-industry spinouts and other new firms the same; the coefficient $\alpha_{1}$ estimates the change in $Y_{i j s t}$, relative to law firms, for non-law firms as a result of a unit change in the enforcement index. Specification (3) is the DIDID specification, where we look for heterogeneous impacts of enforcement based on whether the non-law new firm is a within-industry spinout. The coefficient of interest is $\beta_{1}$, which represents how a one standard deviation increase in CNC enforcement increases $Y_{i j s t}$ for non-law within-industry spinouts relative to other new non-law firms (relative to the corresponding difference between within-industry law spinouts and other new law firms). ${ }^{18}$

Included in $Z_{i j s t}$ are firm level and industry level characteristics. In the employment and survival regressions, we present two sets of estimates - one with log of initial employment as a control and one without such a control - to examine to what extent CNC affect outcomes beyond simply the initial size. At the industry level, we include the log of the total number of firms and the log of total employment at the state-industry-year level and at the state-year level. In addition, the industry share of total number of firms and total employment are included. We include these variables because industry employment represents the pool of talent from which the new firm can recruit, and hence, are likely to be correlated with the propensity for the creation and subsequent growth of a new firm. Note that including these size of industry variables may be overly conservative since they are also affected by CNC enforcement: if firms in certain industries prefer (or do not prefer) high enforcing states then the size of an industry in a given state-industry-year may be correlated with CNC enforcement. By controlling for industry size, we factor out this effect from the enforcement coefficient. There is also a dummy equal to one for a firm being in Louisiana between 2002 and 2003, which represents the only major CNC reversal in our time frame. To help isolate the impact of $\mathrm{CNC}$ enforcement, we include the following state level regressors: exceptions

\footnotetext{
${ }^{18}$ Since CNC enforcement policies only affect workers who have signed CNC, which we cannot observe in our data, our estimates reflect intention to treat effects. While identifying the impact of the treatment on the treated would also be informative, this is the parameter that state legislatures care about because they can only choose the enforcement policy; they cannot force firms to use CNC in their employment contracts.
} 
to at-will employment (Autor et al., 2006), top state corporate tax rates, and whether the state is a right to work state, all interacted with the non-law firm dummy. To account for time-varying industry trends such as industry-wide productivity gains or technological improvements that affect entry, size, growth, and survival, all specifications include 4 digit NAICS by year fixed effects. Note that these are considerably more conservative than including separate industry and year effects, which would not control for such factors.

The advantage of using lawyers as a control group in a DID approach is not only being able to use all the data in our sample, but also being able to use state fixed effects, which account for other non-time varying state-specific effects. Thus, any other potentially confounding variables must not only differentially affect law and non-law firms, but must also be correlated with CNC enforcement. One such possible reason is that lawyers actually enforce CNC. Given that all employment disputes in 2005 made up only 2.1\% (Langton and Cohen, 2008) of all civil state court cases, this potential effect is likely to be small. A related possibility is that law firms make indirect attempts at restricting the mobility of their employees (e.g., by writing and litigating more complicated employment contracts). To the extent that higher enforcing states also enforce these indirect attempts at restricting the ability of lawyers to practice, this will also bias our estimates towards zero because it makes law firms similar to other firms along the enforcement dimension.

The benefit of using all industries in our baseline analyses is that it allows us to examine the aggregate impact of $\mathrm{CNC}$ enforcement across the economy. Using a narrower subset of industries would result in estimates that are less likely to be generalizable. This is particularly likely to be true if the prevalence of $\mathrm{CNC}$ is higher in some industries than in others, in which case the magnitudes of the estimates based on such industries are likely to be biased upward. However, it also raises a potential concern about the differences between law firms and other firms. Though law firms face many of the same economic factors that affect other firms, such as a weak economy (Strickler, 2014; Kessenides, 2014; The Economist, Jan 18, 2014), law firms differ from other industries on several dimensions. For instance, law firms tend to be smaller, more focused on client relationships, and rely more on human capital. ${ }^{19}$ If some of these differences vary across states and those inter-state

\footnotetext{
${ }^{19}$ As a rough check of the similarity of entry behavior between law firms and other firms, we computed the Spearman's rank correlation between annual entry rates of new firms (and within-industry spinouts) in the law industry and every other 4-digit NAICS industry in California. We chose California since it does not enforce CNC,
} 
variations are correlated with overall $\mathrm{CNC}$ enforcement, then it will bias our estimates. Though we cannot completely rule out such a possibility, there are many reasons why factors unique to lawyers will not be a significant determinant of our results. First, for these factors to bias our estimates, they must not only be unique to law firms but also vary across states in a way that the variations are correlated with CNC enforcement. This is unlikely. Also, as we will discuss in the Robustness Checks section, our results are qualitatively similar in subsamples of industries where human capital is important (professional services and technology industries). Furthermore, and perhaps most importantly, we rely on a triple-difference in our empirical estimation with a focus on within-industry spinouts. Hence, even if the unobserved variables are unique to law firms and correlated with CNC enforcement, they will not affect the results along as those variables affect both within-industry law spinouts and other new law firms similarly. For example, suppose high enforcement states have a higher demand for law firms due to, say, a higher propensity to litigate. Then, there may be greater entry of law firms, including smaller law firms. With only two differences (DID) that do not consider within-industry spinouts, this will bias estimates of the impact of CNC enforcement on entry downward and on initial size upward. However, with a third difference, we need additional assumptions that will create a differential effect on within-industry spinouts. Finally, though law firms may differ on many dimensions, the inclusion of both state fixed effects and industry-year fixed effects accounts for all associated differences in the means of those dimensions. Indeed, we verify our within-industry spinout results using state-year-industry fixed effects that rule out any industry-year specific, inter-state variations driving our results.

Another potential concern is that debates on new firm formation are driving changes in the enforcement index. Reverse causality, however, does not appear to be an issue here due to the longstanding nature of these laws and the lack of changes over time. Finally, while the estimates on the enforcement index are likely biased down, the standard errors may also be affected because our estimation procedure does not account for two types of measurement error in our enforcement index. First, each of the dimensions of CNC enforcement are measurement error ridden proxies of latent enforcement intensity. Second, there is error in the factor analysis process and also has relatively long history in the data (1991-2008). Though we cannot disclose the quantitative results due to US Census Bureau disclosure constraints, these correlations were positive and significant in a majority of the industries, suggesting that similar factors affect the entry of law firms and other firms. 
which generates the enforcement index that is not accounted for. Since we cannot completely rule out this possibility, we corroborate our findings by re-running all our specifications using different versions of the enforcement index, including the Garmaise (2011) indices from 1992 and 2001. If the error is contained in the factor analysis generation process, then the Garmaise indices should not be contaminated.

\section{RESULTS}

Table 3 presents the main results of our analyses. Throughout these analyses, the aggregated indices are normalized to be mean 0 , standard deviation 1 , and standard errors are clustered at the state level. Panel A examines the impact of CNC enforcement on the entry rate of within-industry spinouts, non-within-industry spinouts, and all new firms. The entry rates for each category are defined as the ratio of the number of new firms in that category to the total number of establishments in a given state-industry-year. The table provides the coefficient on the interaction between the enforcement index and a non-law dummy, $\gamma_{1}$. The estimates show that a one standard deviation increase in $\mathrm{CNC}$ enforcement decreases the entry rate of within-industry spinouts by 0.13 percentage points, and is significant at the $5 \%$ level. The corresponding point estimates for the entry rates of non-within-industry spinouts and all new firms together are 0.074 and -0.052 respectively, both not statistically different from zero. These creation results suggest that CNC enforcement decreases the entry rate of within-industry-spinouts, but has no significant effect on other new ventures.

The first section of Panel B in Table 3 examines the impact of CNC enforcement on the log employment in the year of the firm's founding, and in year 3, year 5, and year 7. A one standard deviation increase in $\mathrm{CNC}$ enforcement increases the initial size of within-industry spinouts relative to other new firms by $1.1 \%$. In contrast, the initial size effect for all firms is negative and only weakly significant. As can be seen in columns (1) and (2), the pattern of larger within-industry spinouts in higher enforcing states continues to hold for years 3, 5, and 7, but the corresponding effects on all new firms is negative and insignificant in all specifications except with Year 5 employment.

Because initial size is highly correlated with size at year 3,5, and 7 and because the selection induced by CNC enforcement is likely to most directly affect initial size, columns (3) and (4) examine the impact of $\mathrm{CNC}$ enforcement on firm size in years 3, 5, and 7 after controlling for 
initial size. The estimates suggest that conditional on initial size, within-industry spinouts tend to outpace other new firms in higher enforcing states for the first three years. In particular, a one standard deviation increase in $\mathrm{CNC}$ enforcement results in a $0.42 \%$ increase in the size of within-industry spinouts relative to other new ventures between years 0 and 3 . However, as the estimates for years 5 and 7 show, this relative growth advantage for within-industry spinouts in higher enforcing states becomes statistically insignificant over the long-term. The estimates of the effect of CNC enforcement on growth of all new firms, conditional on initial size, are always very small and statistically insignificant.

The last section of Panel B in Table 3 examines the impact of $\mathrm{CNC}$ enforcement on the likelihood that new firms survive beyond the first, second, and third years of their life. That is, the dependent variables are dummies for if the firm survived beyond year 1, 2, and 3. As before, columns (1) and (2) do not control for initial firm size, while columns (3) and (4) do. As the estimates in Column (1) show, relative to other new ventures, within-industry spinouts are more likely to survive the first two years of their life: for a one standard deviation increase in CNC enforcement they are 0.12 percentage points more likely to survive their first year than other new firms, and 0.15 percentage points more likely to survive the second year. Like the difference in growth, the difference in survival between within-industry-spinouts and other new ventures disappears by year three. In contrast to this, Column (2) shows that new ventures founded in higher enforcing states have a lower likelihood of survival in each of the first three years of their creation, suggesting hiring barriers associated with CNC are affecting them.

Since firms that start larger are likely to survive longer, columns (3) and (4) examine how controlling for initial size affects the impact of CNC enforcement on the likelihood of firm survival. The results show that including initial size considerably mitigates the effects seen in Columns (1) and (2), strongly suggesting a selection effect, particularly among within-industry spinouts. For example, conditional on initial size, a one standard deviation increase in CNC enforcement increases the probability that within-industry spinouts survive past the first year by only 0.07 percentage points, which is only weakly significant, and about $42 \%$ smaller than the corresponding unconditional effect in Column (1). The effect for all new firms are also mitigated by the inclusion of initial size though the impact is somewhat smaller. 
Together, these results strongly suggest that CNC enforcement has an effect on the life cycle of within-industry spinouts. Furthermore, the results indicate that, while higher enforcement reduces the entry rate of within-industry spinouts, the within-industry spinouts that are created tend to be larger than other new ventures, are more likely to survive past their nascent years, and grow faster during those years. This is consistent with CNC enforcement acting as an entry barrier that reduces the entry of within-industry spinouts, but increases the quality of those that are created. The fact that the differential effects between within-industry spinouts and other new firms are mitigated with the inclusion of initial size as a control suggests that the primary role of CNC enforcement is on the characteristics of new firms when they are formed.

\section{Additional Evidence on Selection}

If $\mathrm{CNC}$ enforcement has a selection effect on the formation of within-industry spinouts, then we should expect to see systematic differences in the type of founders that establish those spinouts as well as in the kind of parent firms that give rise to such spinouts. This subsection presents results that shed light on this aspect. In order to perform this analysis, we limit the sample to those new firms for which we could directly identify the founders (i.e., the initial cluster of employees who moved from an incumbent to the new firm) as well as the parent establishment where those founders were employed prior to the founding of the new firm. We then analyze if the founders' prior earnings and parent firm characteristics were systematically correlated with CNC enforcement. In particular, we re-estimate Equations (2) and (3) with the following dependent variables: (i) (log) mean earnings of the founders at the parent establishment in the quarter they moved to form the new firm (ii) (log) employment at the parent establishment and (iii) (log) number of establishments at the parent firm. Summary statistics for these variables can be found in Table 1. Throughout, we include fixed effects for each state and each 4-digit NAICS industry-year combination, where the industry pertains to the parent establishment. ${ }^{20}$

The results are presented in Table 4. Like many of the coefficients before, the overall effect on all new firms $\left(\alpha_{1}\right)$ is generally insignificant. In contrast, the $\beta_{1}$ coefficients are mostly significant suggesting that $\mathrm{CNC}$ enforcement has a particularly strong influence on the process of formation of within-industry spinouts. First, we examine how CNC enforcement affects which types of founder

\footnotetext{
${ }^{20}$ We repeated these analyses with the new firm industry fixed effects and found those results to be very similar.
} 
decide to create within-industry spinouts. We find that a one standard deviation increase in CNC enforcement increases the mean of within-industry spinout founder earnings at their parent firm by $1.7 \%$ relative to founders of other new ventures. That is, in higher enforcing states, founders of within-industry spinouts are more likely to have earned a higher wage with their parent firm. Thus, it appears that individuals with lower human capital are less likely to start new firms in high enforcement states.

With regard to the parent characteristics of within-industry spinouts, we find that higher enforcement is associated with within-industry spinouts being founded from smaller parent firms. This is consistent with CNC enforcement having a selection effect. Since smaller parents are less likely to have the required financial and legal resources, they are less likely to pursue CNC related litigation with a departing employee. Relatedly, in higher enforcing states, within-industry spinouts are more likely to be founded from parents with fewer establishments.

Together with the life-cycle results, these results strongly support the argument that CNC enforcement has a selection effect on the formation of within-industry spinouts.

\section{Robustness Checks}

We performed several checks to assess the robustness of our analyses. We discuss them in this subsection. ${ }^{21}$

\section{Alternative measures of CNC enforcement.}

Our baseline analysis uses the factor-analysis-weighted index constructed from the 1991 data in Bishara (2011), which captures CNC enforcement with finer granularity than the Garmaise (2011) indices. Though highly correlated with the Garmaise (2011) indices, there are some differences between the two sets of indices. To ensure that our results were not driven by the choice of this index, we repeated our analyses with the Garmaise (2011) indices for 1992 and 2001. Further, we also re-estimated our results using the factor-analysis-weighted-index constructed from the 2009 data in Bishara (2011) instead of 1991. Tables 7 through 9 in Appendix A present these results for each entry, initial size, growth, and survival. These results are qualitatively similar to those from

\footnotetext{
${ }^{21}$ We are unable to present the results on some of these checks because they generate several dozen samples including implicit samples that significantly increase the associated disclosure risks to the US Census Bureau.
} 
our baseline, Table 3. In addition to ruling out potential issues with our index, the results using Garmaise (2011) indices, which have a lower variance than our baseline index, also indicate that the baseline results are not unduly influenced by the states at the ends of the enforcement index (e.g., California and Florida).

Alternative subsamples.

Using all industries in the estimation provides an accurate picture of the overall impact of CNC enforcement. Despite the use of industry-year fixed effects in the specifications, law firms may be a poor control for firms that function very differently, such as highly capital intensive industries like manufacturing. To ensure that our results are consistent with industries that are more similar to law firms, we first restrict the sample to professional services industries, including Professional, Scientific and Technical Services (NAICS 54) and Administrative and Support Services (NAICS 561), and second to technology industries defined by Paytas and Berglund (2004). The estimates are qualitatively similar to those in Table 3, which shows that the main estimates are not driven by the peculiarities of law as a control group.

\section{Alternative specifications.}

In addition to the baseline specifications presented in Table 3, we re-estimated Equations (2) and (3) without including state fixed effects, and (3) including state-year-fixed effects (which subsumes $\alpha_{1}$ in (2) and $\beta_{2}$ in (3)). The results without state fixed effects are similar to those in Table 3, and thus are not presented. For parent and founder characteristics, Table 5 shows that the estimates are robust to not using state fixed effects and to using state-industry-year fixed effects. Table 6, which presents the results from Table 3 with state-industry-year fixed effects, confirms that the within-industry spinout results are not sensitive to including state-industry-year fixed effects. For

completeness, Table 10 and 11 in Appendix B show the full series of $\beta$ coefficients from estimating equation (3).

\section{DISCUSSION AND CONCLUSION}

This study uses data on 5.5 million new firms formed between 1990 and 2008 across 30 states, and finds that $\mathrm{CNC}$ enforcement has a large impact on the life cycle of within-industry spinouts. Relative to other new firms, increases in CNC enforcement result in fewer, but larger within-industry 
spinouts that grow faster and are more likely to survive their first few years. Furthermore, including initial size as a control appears to significantly diminish any growth and survival effects beyond the first few years. Based on our results in Table 3, if California adopted Florida's CNC laws, it would result in a 0.62 percentage point decrease in the entry rate of within-industry spinouts in California, but those spinouts that are established would be $5.5 \%$ larger, 0.6 percentage points more likely to survive the first year, and 0.74 percentage points more likely to survive the second year. By age 3 , conditional on initial size, the surviving within-industry spinouts would be $2 \%$ larger than other new firms, but over the longer-term this difference would dissipate.

The simplest explanation for our results is that $\mathrm{CNC}$ enforcement has a selection effect on the formation of within-industry spinouts. Specifically, CNC enforcement acts as an 'entry barrier' or as an additional cost that within-industry spinouts in high enforcement states must pay to enter and operate in the market. This cost could be a combination of the costs associated with CNC litigations (e.g., legal defense costs) and costs such as the higher cost of hiring employees and potential loss of business. Other things being equal, this additional cost implies lower entry among entrepreneurs with lower quality ideas and resources in high enforcement states. This, in turn, results in higher observed initial employment since entrepreneurs with higher quality ideas and resources are likely to start larger firms (Cooper et al. 1989). This also explains the higher observed growth rate and greater probability of survival in the first few years when the impact of the initial idea quality and founding resources is likely to be most relevant.

Putting some additional structure on the preceding discussion, albeit a bit simplistic, lends greater clarity and leads to a few additional insights. Consider a simple model where firms must pay a CNC related fixed cost $F$ with a probability $\rho(c, \theta)$ where $c$ is the strength of enforcement, $\theta$ is 'quality', broadly defined to include idea quality and founder resources, and $\rho$ is strictly increasing in both arguments. If $v(\theta, p)$ is the value of a price-taking firm (to the founder) excluding the fixed $\operatorname{cost} F$, and is strictly increasing in both $\theta$ and average industry price $p$, then on average, firms will enter only if $v-\rho F>0$. It follows that there exists a threshold $\theta^{*}$ below which ideas are not transformed to new firms. Furthermore, keeping all else constant, it is easy to see that this threshold is increasing in $c$. This structure also suggests that even if higher human capital founders (e.g., senior managers at the parent firms) are more likely to invite litigation, the impact of that 
increased probability of litigation is not large enough to keep them from entering. In particular, if $\rho($.$) were increasing sharply enough in \theta$, founders with higher $\theta$ would find that the cost of litigation would outweigh the benefit of founding a firm, and hence be more dissuaded by CNC enforcement than those with lower $\theta$. In that case, the threshold $\theta^{*}$ and initial firm size would decrease as enforcement increased, which would be inconsistent with our findings. Further, this structure also sheds light on the strength of an alternative mechanism that would increase the performance of within-industry spinouts: increased investment by parent firms to develop the human capital of their employees. Stricter CNC enforcement buys the loyalty of employees who sign CNC, and therefore provides firms with a higher incentive to invest in training, $R \& D$, and share sensitive information with their employees. These investments may provide employees with high quality ideas and human capital to start new firms. The effect of this would be to increase the mean of $\theta$ in high-enforcement states which, keeping other things equal, would increase entry of withinindustry spinouts. In contrast, we find a negative relation between entry and CNC enforcement suggesting that the selection effect outweighs this potential benefit. Finally, since reduced entry potentially increases industry prices, this would imply a lower propensity to exit (across all age cohorts) as enforcement increases. That we do not find such an effect beyond age 2 suggests that increased enforcement is likely not associated with an increase in prices large-enough to decrease the propensity to exit. This may happen either because the reduction in entry itself is low or more likely because other types of entrants such as diversifying entrants and new ventures of incumbents fill the void left by within-industry spinouts.

Other evidence also points toward CNC having a selection effect. First, we find that the average prior earnings of within-industry spinout founders is higher in high enforcement states. This is consistent with CNC enforcement deterring individuals with lower human capital from starting within-industry spinouts. Second, within-industry spinouts tend to have smaller parents in high enforcement states. This is also consistent with the presence of a selection effect. In these states, parent firms have a higher probability of a successful outcome in a CNC litigation, which encourages even small parent firms who would not pursue such litigation in low enforcement states to do so in high enforcement states. Consequently, we observe a reduction in the average parent 
size of within-industry spinouts. ${ }^{22}$ Finally, we find that while CNC enforcement is associated with higher probability of survival in the first few years, the significance of this effect disappears after one year when we include initial firm size as a control in the regressions. Combined with the fact that we see no impact on long-term growth rates and survival, this strongly suggests that the impact of $\mathrm{CNC}$ enforcement on the performance of new firms is primarily through its effect on initial firm size.

These findings are broadly consistent with studies that argue $\mathrm{CNC}$ reduce the mobility of individuals including those of entrepreneurs from their employers (e.g., Samila and Sorenson, 2011; Marx et al., 2009). Our finding of lower entry rate of within-industry spinouts is in line with that argument, though our results suggest that the effect of CNC enforcement is largely limited to withinindustry spinouts and that there is little overall effect on all new firms. In this narrow respect, our results appear to be somewhat different from Samila and Sorenson (2011). However, since there are significant differences in the data and empirical design between the two studies, a direct comparison may not be very meaningful. ${ }^{23}$ More broadly, our results highlight the importance of treating within-industry spinouts differently from other types of new firms, given their unique relationship to their parent firms. Going beyond entry, our study suggests that CNC enforcement has a longer and heterogeneous impact on new firms. Though it has been known that stricter CNC enforcement likely deters entry, to our knowledge this is the first investigation of post-entry performance and CNC enforcement. By examining initial size, growth and survival, our study sheds light on the potential mechanism, viz. selection, that links CNC enforcement to lower entrepreneurial activity.

Together, our results have implications for research on new venture formation and entrepreneurship, as well as for managers concerned about new entry. They suggest that the effect

\footnotetext{
${ }^{22}$ An alternative explanation that partially explains these results is that entrepreneurs need to be 'jacks of all trades' and small firms provide more opportunities to be so (Lazear, 2004). However, this explanation does not explain why there should be differences between within- and out-of- industry spinouts or between law firms and other firms or why there should be a correlation with the enforcement index.

${ }^{23}$ There are three main areas of difference. First, their measure of the number of new firms is the number of new establishments whose enterprise size (e.g. the summed employment of all associated establishments) is between 0 and 19. These new establishments include those created by incumbent firms, while our data includes only new firms. Second, they measure the elasticity of new establishment formation with respect to venture capital investment and how the elasticity is affected by CNC. We measure the effect of CNC on new firm formation directly. Third, they assume all types of new firms in all industries are equally affected by CNC through venture capital investment, while we distinguish the types of new firms which are most likely to be affected by CNC and control for industry-specific effects by including industry-fixed effects.
} 
of $\mathrm{CNC}$ enforcement is not limited to its effect on the mobility of workers or the formation of new firms, but also extends to the size, growth and survival of new firms. Our study also implies that in order to evaluate its full impact, we should examine the effect of $\mathrm{CNC}$ enforcement on the whole process of new venture formation, and not just on entry. While CNC enforcement can reduce the rate of within-industry spinout formation, this reduction is likely the result of reduced entry by within-industry spinouts with lower quality ideas or resources. Hence, strong CNC enforcement might not necessarily reduce the level of competitive threats to incumbents from within-industry spinouts. Furthermore, our study implies that CNC enforcement exhibits complex effects on the development of regional economies. Similar to patent protection, CNC enforcement protects a firm's intellectual property and increases its incentive to invest in human capital. However, CNC enforcement prevents the dissemination of knowledge embodied in workers, thus it discourages the formation and development of new firms. By analyzing aspects beyond the mobility of workers, our study also contributes to our understanding of the process of how CNC enforcement affects regional development through new firm formation.

Turning to the limitations of our study, we do not consider the possibility that CNC enforcement could change the intensity of industry competition. There may also be longer term effects of competition on innovation, which have been ignored in our study. Similarly, our results do not allow us to estimate the welfare effects of CNC enforcement. Our suggested mechanism of entry and hiring barriers suggest welfare losses but without an analysis of incumbent entry and performance, we cannot quantify the extent of welfare losses. Further, our performance measures are limited to size, growth and survival due to data limitations, but there are other performance measures such as profitability and productivity that can be examined. We leave a comprehensive analysis of these issues as a subject for future research.

A natural extension of this study would be to perform analyses at the individual level instead of the firm level adopted by our study. This may provide insights into how CNC enforcement affects individual entrepreneurial decisions. Future studies could also examine whether or not the dispersion of performance of within-industry spinouts is negatively correlated with CNC enforcement, and in particular if the lower end of the performance distribution (e.g., the $10^{\text {th }}$ percentile) is higher in higher-enforcement states. This would augment the selection argument. Another potentially 
interesting avenue for future research is to examine the inter-industry heterogeneity in the impact of $\mathrm{CNC}$ enforcement in much greater detail. As alluded to earlier, CNC are most effective at protecting assets that can be transferred out through the departure of employees, and when other means to protect those assets are available, such as patents, copyrights, trade secrets, or the need for complementary assets, then this may reduce the benefits of enforcing CNC. Thus, we may see significant inter-industry variation in the effects of CNC enforcement.

To conclude, noncompete agreements do indeed appear to be a 'significant impediment to people who aspire to start their own firms', especially if they want to start a firm that competes with their current employer.

\section{REFERENCES}

Agarwal, Rajshree, Raj Echambadi, April Franco, and MB Sarkar. 2004. Knowledge Transfer through Inheritance: Spinout Generation, Development, and Survival. Academy of Management Journal 47(4): 501-522.

Autor, David, John Donohue III and Stewart Schwab. 2006. The Costs of Wrongful-Discharge Laws. Review of Economics and Statistics 88(2): 211-231.

Barney, Jay. 1991. Firm resources and sustained competitive advantage. Journal of Management, 17(1): 99-120.

Bishara, Norman. 2011. Fifty Ways to Leave Your Employer: Relative Enforcement of Noncompete Agreements, Trends, and Implications for Employee Mobility Policy. University of Pennsylvania Journal of Business Law, Vol 13.

Blake, Harlan. 1960. Employee Agreements Not to Compete. Harvard Law Review, 73:625691.

Buffkin, Russell C. 1991. Non-Competition Clauses in Law Firm Partnership Agreements: How Far Can Partnership Agreements Control Future Conduct of 'Lawyers?' The Journal of the Legal Profession, 23:325-336.

Campbell, Benjamin A., Martin Ganco, April M. Franco and Rajshree Agarwal. 2012. Who 
Leaves, Where to, and Why Worry? Employee Mobility, Entrepreneurship and Effects on Source Firm Performance. Strategic Management Journal, 33(1): 65-87.

Chatterji, Aaron K. 2009. Spawned with a Silver Spoon? Entrepreneurial Performance and Innovation in the Medical Device Industry. Strategic Management Journal 30(2): 185-206.

Conti, Raffaele. 2013. Do Non-competition Agreements Lead Firms to Pursue Risky R\&D Projects? Strategic Management Journal Online Version DOI: 10.1002/smj.2155

Cooper, Arnold C., Carolyn Y Woo and William C Dunkelberg. 1989. Entrepreneurship and the Initial Size of Firms. Journal of Business Venturing, 4(5), 317-332

Economist, The. Jan 18th 2014. Charging more, getting less. Lawyers' biggest customers are discovering that they can haggle. Accessed at http://www.economist.com/news/business/21594317lawyers-biggest-customers-are-discovering-they-can-haggle-charging-more-getting-less on June 6 , 2014.

Fallick, Bruce, Charles Fleischman, and James Rebitzer. 2006. Job-Hopping in Silicon Valley: Some Evidence Concerning the Micro-Foundations of a High Technology Cluster. Review of Economics and Statistics, 88: 472-81.

Fosfuri, Andrea and Thomas Ronde. 2004. High-tech Clusters, Technology Spillovers, and Trade Secret Laws. International Journal of Industrial Organization, 22(1) 45-65.

Franco, April M. and Matthew F. Mitchell. 2008. Covenants Not to Compete, Labor Mobility, and Industry Dynamics. Journal of Economics and Management Strategy, 17(3): 581-606.

Garmaise, Mark. 2011. Ties That Truly Bind: Non-competition Agreements, Executive Compensation, and Firm Investment. Journal of Law, Economics, and Organization, 27: 376-425.

Gilson, Ronald. 1999. The Legal Infrastructure of High Technology Industrial Districts: Silicon Valley, Route 128, and Covenants Not to Compete. New York University Law Review, 74:575-629.

Grant, Robert M. 1996. Toward a knowledge-based theory of the firm. Strategic Management Journal, 17(summer special issue): 109-122. 
Grossman, Sanford J. and Oliver D. Hart. 1986. The Costs and Benefits of Ownership: A Theory of Vertical and Lateral Integration. Journal of Political Economy, 94(4): 691-719.

Glynn, Timothy. 2008. Interjurisdictional Competition in Enforcing Noncompetition Agreements: Regulatory Risk Management and the Race to the Bottom. Washington and Lee Law Review, 65:1381-1444.

Hart, Oliver D. and John Moore. 1990. Property Rights and the Nature of the Firm. Journal of Political Economy, 98(6): 1119-58.

Kessenides, Dimitra. 2014. Why It's Time for Big Law to 'Adapt or Die'. Accessed at http://www.businessweek.com/articles/2014-01-03/why-its-time-for-big-law-to-adapt-or-die on June 6,2014 .

Klepper, Steven. 2001. Employee Startups in High-Tech Industries. Industrial and Corporate Change 10(3): 639-674.

Klepper, Steven, and Sally Sleeper. 2005. Entry by Spinoffs. Management Science 51(8): 1291-1306.

Klepper, Steven. 2007. Disagreements, Spinoffs, and the Evolution of Detroit as the Capital of the U.S. Automobile Industry. Management Science 53(4): 616-631.

Klepper, Steven. 2009. Spinouts: A Review and Synthesis. European Management Review 6(3): 159-171.

Langton, Lynn and Thomas Cohen. 2008. Civil Bench and Jury Trials in State Courts, 2005. Accessed at http://www.bjs.gov/content/pub/pdf/cbjtsc05.pdf on October 3rd, 2013.

Lazear, Edward P. 2004. Balanced Skills and Entrepreneurship. American Economic Review Papers and Proceedings, 94(2): 208-211.

Lerner, Josh. 1995. Patenting in the Shadow of Competitors. Journal of Law and Economics 38(2): 463-95.

Malsberger, Brian. 1996. Covenants Not to Compete: A State by State Survey. Washington, DC: Bureau of National Affairs. 
Marx, Matt, Deborah Strumsky and Lee Fleming. 2009. Mobility, Skills, and the Michigan Non-Compete Experiment. Management Science, 55:875-89.

Marx, Matt. 2011. The Firm Strikes Back: Non-Compete Agreements and the Mobility of Technical Professionals. American Sociological Review, 76(5): 695-712

Marx, Matt, Jasjit Singh, and Lee Fleming. 2011. Regional Disadvantage? NonCompete Agreements and Brain Drain. Working paper accessed at http://siepr.stanford.edu /system/files/shared/pubs/papers/braindrain110707[1].pdf on April 30, 2014.

Meccheri, Nicola. 2009. A Note on Noncompetes, Bargaining and Training by Firms. Economic Letters, 102(3):198-200.

Murphy, Kevin M., Andrei Shleifer and Robert W. Vishny. 1991. The Allocation of Talent: Implications for Growth. Quarterly Journal of Economics 106(2): 503-530.

Paytas, Jerry and Dan Berglund. 2004. Technology Industries and Occupations for NAICS Industry Data. Carnegie Mellon Heinz School, Accessed at www.heinz.cmu.edu /download.aspx?id=1338 on March 26, 2014.

Rauch, James E. and Joel Watson. 2014. Client-Based Entrepreneurship. Journal of Law, Economics, and Organization, online advance access doi: 10.1093/jleo/ewt023.

Santarelli, Enrico. and Marco Vivarelli. 2007. Entrepreneurship and the Process of Firms' Entry, Survival and Growth. Industrial and Corporate Change, 16(3): 455-488

Samila, Sampsa and Olav Sorensen. 2011. Noncompete Covenants: Incentives to Innovate or Impediments to Growth. Management Science, 57(3):425-438.

Starr, Evan. 2014. Training the Enemy? Firm-Sponsored Training and the Enforcement of Covenants Not to Compete. Working Paper.

Stone, Katherine. 2002. Knowledge at Work: Disputes Over the Ownership of Human Capital in the Changing Workplace. Connecticut Law Review, 34:721-763.

Strickler, Andrew. 2014. Law Firms Face Sluggish Economic Outlook In 2014. Accessed at http://www.law360.com/articles/489575/law-firms-face-sluggish-economic-outlook-in-2014 on June 
$6,2014$.

Stuart, Toby E. and Olav Sorenson. 2003. Liquidity Events and the Geographic Distribution of Entrepreneurial Activity. Administrative Science Quarterly, 48(2): 175-201.

Stroud, Sela. 2002. Non-Compete Agreements: Weighing the Interests of Profession and Firm. Alabama Law Review, 53(3):1023-1041. 
Table 1: Descriptive Statistics

Panel A: All New Firms

\begin{tabular}{lcccccc}
\hline \hline & \multicolumn{2}{c}{ Full Sample } & \multicolumn{2}{c}{ Law } & \multicolumn{2}{c}{ Non-Law } \\
& Mean & SD & Mean & SD & Mean & SD \\
\hline Within-Industry Spinout Dummy & 0.08 & 0.28 & 0.23 & 0.42 & 0.08 & 0.27 \\
New Firm Entry Rate & 0.10 & 0.10 & 0.07 & 0.02 & 0.10 & 0.10 \\
Non-law Firm Dummy & 0.98 & 0.15 & 0.00 & 0.00 & 1.00 & 0.00 \\
Enforcement & -0.46 & 1.77 & -0.47 & 1.77 & -0.46 & 1.77 \\
Industry Employment & 44996 & 69052 & 51564 & 39853 & 44849 & 69557 \\
Industry Number of Firms & 4303 & 5220 & 9649 & 7032 & 4184 & 5109 \\
Industry Share-Employment & 0.01 & 0.01 & 0.01 & 0.00 & 0.01 & 0.01 \\
Industry Share-Firms & 0.01 & 0.01 & 0.03 & 0.00 & 0.01 & 0.01 \\
$\quad$ Employment & & & & & & \\
Year 0 & 5.86 & 60.50 & 2.92 & 7.30 & 5.93 & 61.20 \\
Year 3 & 7.66 & 55.40 & 3.79 & 8.08 & 7.76 & 56.10 \\
Year 5 & 8.74 & 62.60 & 4.18 & 7.68 & 8.87 & 63.50 \\
Year 7 & 9.64 & 73.70 & 4.51 & 8.44 & 9.80 & 74.80 \\
\hline Observations & \multicolumn{2}{|c}{$5,538,121$} & 120,961 & $5,417,160$ \\
\hline
\end{tabular}

Panel B: Within-Industry Spinouts

\begin{tabular}{lcccccc}
\hline \hline & \multicolumn{2}{c}{ Full Sample } & \multicolumn{2}{c}{ Law } & \multicolumn{2}{c}{ Non-Law } \\
& Mean & SD & Mean & SD & Mean & SD \\
\hline Non-law Firm Dummy & 0.94 & 0.24 & 0.00 & 0.00 & 1.00 & 0.00 \\
$\quad$ Employment & & & & & & \\
Year 0 & 3.89 & 17.4 & 2.33 & 3.44 & 4.00 & 17.9 \\
Year 3 & 5.76 & 50.2 & 3.14 & 4.04 & 5.95 & 52.0 \\
Year 5 & 6.67 & 58.3 & 3.55 & 4.04 & 6.92 & 60.6 \\
Year 7 & 7.36 & 59.2 & 3.90 & 6.74 & 7.67 & 8.17 \\
\hline Observations & \multicolumn{2}{c}{466,116} & \multicolumn{2}{c}{28,106} & \multicolumn{2}{c}{438,010} \\
\hline
\end{tabular}

Panel C: Characteristics of Parents and Spinout Founders

\begin{tabular}{lcccccc}
\hline \hline & \multicolumn{2}{c}{ Full Sample } & \multicolumn{2}{c}{ Law } & \multicolumn{2}{c}{ Non-Law } \\
& Mean & SD & Mean & SD & Mean & SD \\
\hline Mean Earnings of Founders at Parent & 6876 & 47072 & 8543 & 21529 & 6823.76 & 47655 \\
Parent Establishment Size & 1616 & 7559 & 11780 & 6308 & 1630 & 7595 \\
Number of Parent Establishments & 41.92 & 467 & 23.44 & 295 & 42.5 & 471 \\
\hline Observations & \multicolumn{2}{c}{$1,543,651$} & \multicolumn{2}{c}{47,309} & \multirow{2}{*}{$1,496,342$} \\
\hline
\end{tabular}


Table 2: Factor Analysis Index

\begin{tabular}{lccccccc}
\hline \hline \multirow{2}{*}{ Question } & \multicolumn{3}{c}{ 1991 } & \multicolumn{5}{c}{2009} \\
& Mean & SD & FA Weight & Mean & SD & FA Weight & Bishara Weight \\
\hline Statute of Enforceability & 4.90 & 1.53 & 0.07 & 4.96 & 1.79 & 0.09 & 0.10 \\
Protectable Interest & 5.80 & 2.03 & 0.07 & 0.07 & 1.93 & 0.21 & 0.10 \\
Plaintiff's Burden of Proof & 5.36 & 2.06 & 0.06 & 5.59 & 1.93 & 0.13 & 0.10 \\
Consideration At Inception & 8.45 & 2.35 & 0.22 & 8.73 & 2.39 & 0.07 & 0.05 \\
Consideration Post Inception & 7.04 & 2.78 & 0.09 & 7.15 & 2.86 & 0.05 & 0.05 \\
Overbroad Contracts & 5.71 & 3.07 & 0.04 & 5.83 & 2.91 & 0.03 & 0.05 \\
Quit v. Fire & 6.23 & 2.32 & 0.07 & 6.45 & 2.37 & 0.07 & 0.10 \\
\hline \hline
\end{tabular}

Source: Starr(2014)

Figure 1: Factor Analysis Enforcement Index for 2009 and 1991

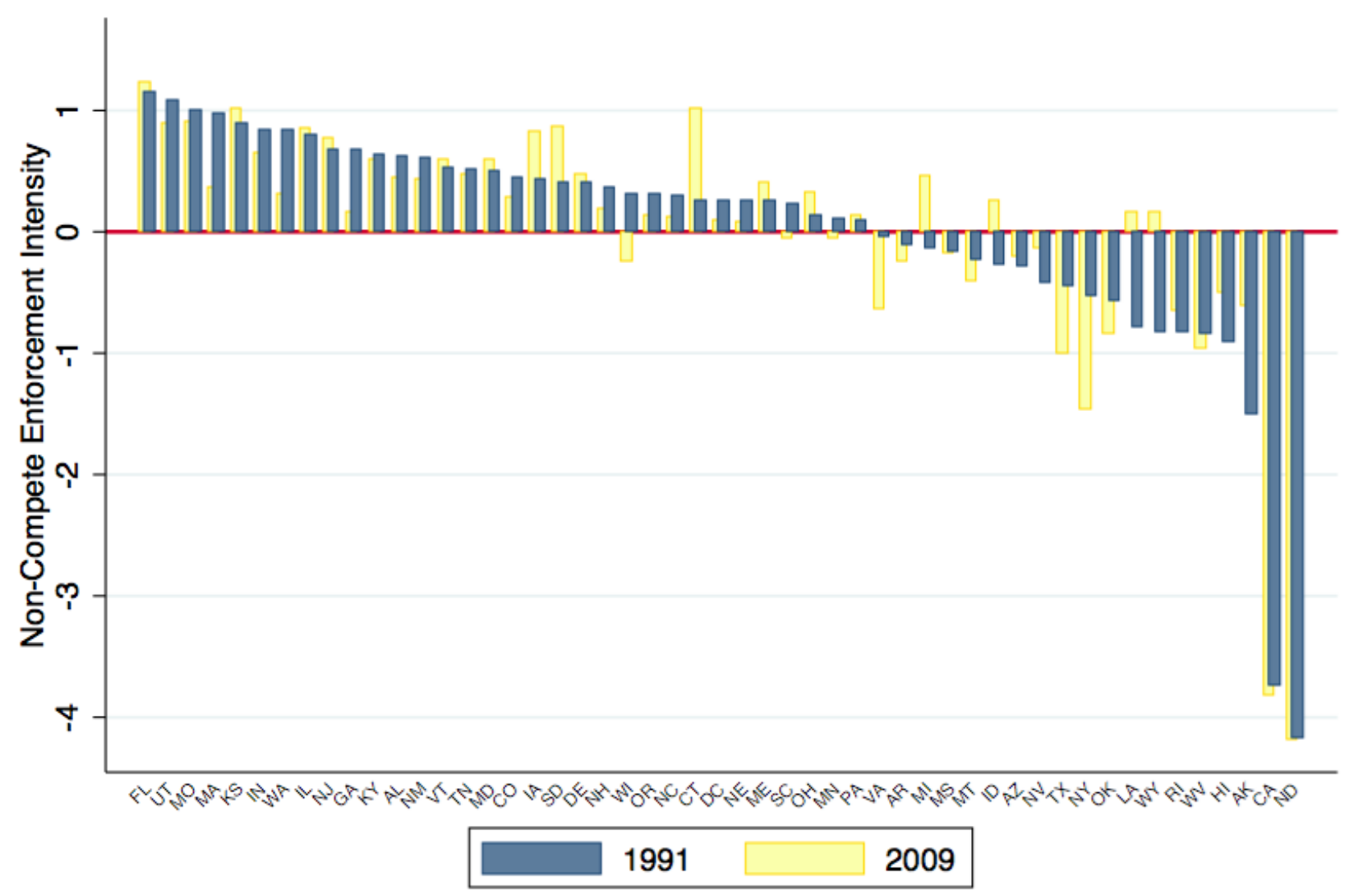

The 1991 and 2009 composite enforcement indices in this bar graph use the 1991 factor analysis weights and the 1991 and 2009 individual enforcement dimension scores. 
Table 3: The Life-cycle Impacts of CNC Enforcement: 1991 Enforcement Index Panel A: Entry Rate Analysis

\begin{tabular}{lccc} 
Dependent Variable & WSO $\left(\gamma_{1}\right)$ & Non-WSO $\left(\gamma_{1}\right)$ & All Firms $\left(\gamma_{1}\right)$ \\
\hline Entry Rate & $-0.00126^{* *}$ & 0.00074 & -0.00052 \\
& $(0.00049)$ & $(0.00120)$ & $(0.00117)$ \\
\hline
\end{tabular}

Panel B: Employment Growth and Survival Analysis

\begin{tabular}{|c|c|c|c|c|}
\hline Dependent Variable & $\begin{array}{c}(1) \\
\text { WSO }\left(\beta_{1}\right)\end{array}$ & $\begin{array}{c}(2) \\
\text { All Firms }\left(\alpha_{1}\right)\end{array}$ & $\begin{array}{c}(3) \\
\text { WSO }\left(\beta_{1}\right)\end{array}$ & $\begin{array}{c}(4) \\
\text { All Firms }\left(\alpha_{1}\right)\end{array}$ \\
\hline \multicolumn{5}{|l|}{ Log Employment } \\
\hline Year 0 & $\begin{array}{l}0.01132^{* * *} \\
(0.00191)\end{array}$ & $\begin{array}{r}-0.01479^{*} \\
(0.00810)\end{array}$ & & \\
\hline Year 3 & $\begin{array}{l}0.01439^{* * *} \\
(0.00274)\end{array}$ & $\begin{array}{c}-0.01679 \\
(0.00990)\end{array}$ & $\begin{array}{l}0.00416^{* *} \\
(0.00163)\end{array}$ & $\begin{array}{r}-0.00519 \\
(0.00435)\end{array}$ \\
\hline Year 5 & $\begin{array}{l}0.01178^{* * *} \\
(0.00239)\end{array}$ & $\begin{array}{c}-0.02331^{* *} \\
(0.01103)\end{array}$ & $\begin{array}{c}0.00219 \\
(0.00201)\end{array}$ & $\begin{array}{r}-0.01122 \\
(0.00684)\end{array}$ \\
\hline Year 7 & $\begin{array}{l}0.00802^{* *} \\
(0.00378)\end{array}$ & $\begin{array}{r}-0.02162 \\
(0.01412)\end{array}$ & $\begin{array}{r}-0.00203 \\
(0.00244)\end{array}$ & $\begin{array}{r}-0.00640 \\
(0.01033)\end{array}$ \\
\hline $\begin{array}{l}\text { Survival } \\
\text { Survive Year } 1\end{array}$ & $\begin{array}{l}0.00121^{* * *} \\
(0.00036)\end{array}$ & $\begin{array}{c}-0.00202^{* *} \\
(0.00080)\end{array}$ & $\begin{array}{c}0.00070^{*} \\
(0.00038)\end{array}$ & $\begin{array}{c}-0.00135 \\
(0.00080)\end{array}$ \\
\hline Survive Year 2 & $\begin{array}{c}0.00149^{*} \\
(0.00076)\end{array}$ & $\begin{array}{c}-0.00348^{* * *} \\
(0.00106)\end{array}$ & $\begin{array}{c}0.00083 \\
(0.00074)\end{array}$ & $\begin{array}{c}-0.00262^{* *} \\
(0.00113)\end{array}$ \\
\hline Survive Year 3 & $\begin{array}{c}0.00067 \\
(0.00126)\end{array}$ & $\begin{array}{c}-0.00383^{* *} \\
(0.00147)\end{array}$ & $\begin{array}{c}0.00005 \\
(0.00122)\end{array}$ & $\begin{array}{r}-0.00302^{*} \\
(0.00156)\end{array}$ \\
\hline Log Initial Employment & & & $\mathrm{X}$ & $\mathrm{X}$ \\
\hline
\end{tabular}


Table 4: Characteristics of Spinout Founders and Their Parent Firms

(1)

\begin{tabular}{lcc} 
Dependent Variable & WSO $\left(\beta_{1}\right)$ & All Firms $\left(\alpha_{1}\right)$ \\
\hline Log Mean Founder Earnings at Parent & $0.01737^{* *}$ & 0.00410 \\
& $(0.00663)$ & $(0.01905)$ \\
Log Parent Establishment Size & $-0.06358^{* * *}$ & -0.01567 \\
& $(0.01189)$ & $(0.01860)$ \\
Log Number of Parent Establishments & $-0.04206^{* * *}$ & $-0.01895^{* *}$ \\
& $(0.00940)$ & $(0.00822)$ \\
\hline *** p<0.01, ${ }^{* *} \mathrm{p}<0.05,{ }^{*} \mathrm{p}<0.1 . \quad$ This table presents $\beta_{1}$ and $\alpha_{1}$ from \\
regressions of Equations (3) and (2). The left-most column represents \\
the dependent variable. WSO stands for within-industry spinout. Robust \\
standard errors are in parentheses, clustered at the state level. All \\
specifications include state fixed effects, and year by 4 digit NAICS fixed \\
effects. Other controls can be found on page 16.
\end{tabular}

Table 5: Characteristics of Spinout Founders and Their Parent Firms: Robustness Checks

$(1)$

(2)
$(3)$

(4)

$(5)$

\begin{tabular}{lccccc} 
Dependent Variable & WSO $\left(\beta_{1}\right)$ & All Firms $\left(\alpha_{1}\right)$ & WSO $\left(\beta_{1}\right)$ & All Firms $\left(\alpha_{1}\right)$ & WSO $\left(\beta_{1}\right)$ \\
\hline Mean Founder Earn. & $0.01737^{* *}$ & 0.00410 & $0.01715^{* *}$ & 0.00124 & 0.01237 \\
& $(0.00663)$ & $(0.01905)$ & $(0.00667)$ & $(0.01951)$ & $(0.01277)$ \\
Parent Estab. Size & $\begin{array}{c}-0.06358^{* * *} \\
(0.01189)\end{array}$ & $\begin{array}{c}-0.01567 \\
(0.01860)\end{array}$ & $\begin{array}{c}-0.06436^{* * *} \\
(0.01070)\end{array}$ & $\begin{array}{c}-0.01683 \\
(0.01907)\end{array}$ & $-0.06254^{* * *}$ \\
& $\begin{array}{c}0.04206^{* * *} \\
\text { No. Parent Estab. }\end{array}$ & $-0.01895^{* *}$ & $-0.04243^{* * *}$ & $-0.01757^{* *}$ & $-0.02910^{* *}$ \\
& $(0.00940)$ & $(0.00822)$ & $(0.00991)$ & $(0.00843)$ & $(0.01297)$ \\
\hline $\begin{array}{l}\text { State FE } \\
\text { No State FE }\end{array}$ & $\mathrm{X}$ & $\mathrm{X}$ & $\mathrm{X}$ & $\mathrm{X}$ \\
State-Industry-Year FE & & & & $\mathrm{X}$ \\
\hline \hline *** $\mathrm{p}<0.01,{ }^{* *} \mathrm{p}<0.05,{ }^{*} \mathrm{p}<0.1$. & This table presents $\beta_{1}$ and $\alpha_{1}$ from regressions of Equations
\end{tabular}

(3) and (2). The left-most column represents the dependent variable. WSO stands for withinindustry spinout. Robust standard errors are in parentheses, clustered at the state level. All specifications include state fixed effects, and year by 4 digit NAICS fixed effects. Other controls can be found on page 16 . 
Table 6: The Life-cycle Impacts of CNC Enforcement: 1991 Starr-Bishara Enforcement Index with State-Industry-Year Fixed Effects

Panel B: Employment Growth and Survival Analysis

\begin{tabular}{lcc}
\hline \hline & $(1)$ & $(2)$ \\
Dependent Variable & WSO $\left(\beta_{1}\right)$ & WSO $\left(\beta_{1}\right)$ \\
\hline Log Employment & & \\
Year 0 & $0.01033^{* * *}$ & \\
& $(0.00184)$ & \\
Year 3 & $0.01151^{* * *}$ & $0.00343^{* * *}$ \\
& $(0.00275)$ & $(0.00117)$ \\
Year 5 & $0.00704^{* *}$ & 0.00023 \\
& $(0.00273)$ & $(0.00189)$ \\
Year 7 & 0.00405 & -0.00273 \\
& $(0.00413)$ & $(0.00204)$ \\
Survival & & \\
Survive Year 1 & $0.00104^{* *}$ & 0.00057 \\
Survive Year 2 & $(0.00050)$ & $(0.00050)$ \\
& $0.00144^{* *}$ & 0.00084 \\
Survive Year 3 & $(0.00059)$ & $(0.00060)$ \\
& 0.00118 & 0.00060 \\
& $(0.00103)$ & $(0.00099)$
\end{tabular}

\begin{tabular}{lc}
\hline Log Initial Employment & $\mathrm{X}$ \\
\hline \hline *** $\mathrm{p}<0.01,{ }^{* *} \mathrm{p}<0.05,{ }^{*} \mathrm{p}<0.1$. & This table presents
\end{tabular}

$\beta_{1}$ and $\alpha_{1}$ from regressions of Equations (3) and (2). The left-most column represents the dependent variable. WSO stands for within-industry spinout. Robust standard errors are in parentheses, clustered at the state level. All specifications include state-industry-year fixed effects. Other controls can be found on page 16 . 


\section{Appendix}

\section{A Robustness Checks with Different Enforcement Indices}

Table 7: The Life-cycle Impacts of CNC Enforcement: 2009 Enforcement Index Panel A: Entry Rate Analysis

(1)

\begin{tabular}{lccc} 
Dependent Variable & WSO $\left(\gamma_{1}\right)$ & Non-WSO $\left(\gamma_{1}\right)$ & All Firms $\left(\gamma_{1}\right)$ \\
\hline Entry Rate & $-0.00087^{*}$ & 0.00054 & -0.00033 \\
& $(0.00046)$ & $(0.00092)$ & $(0.00107)$ \\
\hline
\end{tabular}

Panel B: Employment Growth and Survival Analysis

(1)

(2)

(3)

(4)

\begin{tabular}{lcccc} 
Dependent Variable & WSO $\left(\beta_{1}\right)$ & All Firms $\left(\alpha_{1}\right)$ & WSO $\left(\beta_{1}\right)$ & All Firms $\left(\alpha_{1}\right)$ \\
\hline Log Employment & & & & \\
Year 0 & $0.01202^{* * *}$ & $-0.01467^{*}$ & & \\
& $(0.00182)$ & $(0.00722)$ & & \\
Year 3 & $0.01575^{* * *}$ & $-0.01971^{*}$ & $0.00507^{* * *}$ & -0.00644 \\
& $(0.00222)$ & $(0.01049)$ & $(0.00131)$ & $(0.00516)$ \\
Year 5 & $0.01170^{* * *}$ & $-0.02648^{* *}$ & 0.00329 & $-0.01301^{*}$ \\
& $(0.00214)$ & $(0.01142)$ & $(0.00215)$ & $(0.00762)$ \\
Year 7 & $0.00936^{* * *}$ & -0.02275 & 0.00039 & -0.00697 \\
& $(0.00291)$ & $(0.01469)$ & $(0.00205)$ & $(0.01104)$ \\
\multicolumn{1}{c}{ Survival } & & & & \\
Survive Year 1 & $0.00088^{* *}$ & -0.00057 & 0.00034 & 0.00008 \\
Survive Year 2 & $(0.00038)$ & $(0.00084)$ & $(0.00040)$ & $(0.00096)$ \\
Survive Year 3 & $0.00154^{*}$ & -0.00148 & 0.00084 & -0.00063 \\
& $(0.00081)$ & $(0.00122)$ & $(0.00080)$ & $(0.00133)$ \\
& 0.00030 & -0.00244 & -0.00036 & -0.00163 \\
Log Initial Employment & $(0.00148)$ & $(0.00164)$ & $(0.00144)$ & $(0.00166)$ \\
\hline
\end{tabular}

${ }^{* * *} \mathrm{p}<0.01,{ }^{* *} \mathrm{p}<0.05,{ }^{*} \mathrm{p}<0.1$. This table presents $\beta_{1}$ and $\alpha_{1}$ from regressions of Equations (3) and (2). The left-most column represents the dependent variable. WSO stands for within-industry spinout. Robust standard errors are in parentheses, clustered at the state level. All specifications include state fixed effects, and year by 4 digit NAICS fixed effects. Other controls can be found on page 16 . 
Table 8: The Life-cycle Impacts of CNC Enforcement: 1992 Garmaise Enforcement Index Panel A: Entry Rate Analysis

\begin{tabular}{lccc} 
Dependent Variable & WSO $\left(\gamma_{1}\right)$ & Non-WSO $\left(\gamma_{1}\right)$ & All Firms $\left(\gamma_{1}\right)$ \\
\hline Entry Rate & -0.00055 & 0.00066 & 0.00011 \\
& $(0.00067)$ & $(0.00104)$ & $(0.00103)$ \\
\hline
\end{tabular}

Panel B: Employment Growth and Survival Analysis

(3) $(4)$

\begin{tabular}{lcccc} 
Dependent Variable & WSO $\left(\beta_{1}\right)$ & All Firms $\left(\alpha_{1}\right)$ & WSO $\left(\beta_{1}\right)$ & All Firms $\left(\alpha_{1}\right)$ \\
\hline \multicolumn{1}{c}{ Log Employment } & & & & \\
Year 0 & $0.01430^{* * *}$ & -0.01573 & & \\
& $(0.00371)$ & $(0.00940)$ & & \\
Year 3 & $0.01807^{* * *}$ & -0.01817 & $0.00557^{*}$ & -0.00614 \\
& $(0.00465)$ & $(0.01473)$ & $(0.00287)$ & $(0.00709)$ \\
Year 5 & $0.01316^{* *}$ & -0.02413 & 0.00296 & -0.01256 \\
& $(0.00537)$ & $(0.01569)$ & $(0.00399)$ & $(0.00866)$ \\
Year 7 & 0.00942 & -0.01916 & -0.00108 & -0.00620 \\
& $(0.00575)$ & $(0.01846)$ & $(0.00356)$ & $(0.01206)$ \\
\multicolumn{1}{c}{ Survival } & $0.00151^{* * *}$ & -0.00217 & 0.00087 & -0.00146 \\
Survive Year 1 & $(0.00049)$ & $(0.00145)$ & $(0.00054)$ & $(0.00150)$ \\
& 0.00124 & -0.00338 & 0.00042 & -0.00247 \\
Survive Year 2 & $(0.00143)$ & $(0.00231)$ & $(0.00135)$ & $(0.00233)$ \\
Survive Year 3 & 0.00005 & $-0.00494^{*}$ & -0.00073 & -0.00408 \\
& $(0.00199)$ & $(0.00258)$ & $(0.00187)$ & $(0.00257)$ \\
\hline Log Initial Employment & & & $\mathrm{X}$ & $\mathrm{X}$ \\
\hline \hline
\end{tabular}
*** $\mathrm{p}<0.01,{ }^{* *} \mathrm{p}<0.05,{ }^{*} \mathrm{p}<0.1$. This table presents $\beta_{1}$ and $\alpha_{1}$ from regressions of Equations (3) and (2). The left-most column represents the dependent variable. WSO stands for within-industry spinout. Robust standard errors are in parentheses, clustered at the state level. All specifications include state fixed effects, and year by 4 digit NAICS fixed effects. Other controls can be found on page 16. 
Table 9: The Life-cycle Impacts of CNC Enforcement: 2001 Garmaise Enforcement Index Panel A: Entry Rate Analysis

\begin{tabular}{lccc} 
Dependent Variable & WSO $\left(\gamma_{1}\right)$ & Non-WSO $\left(\gamma_{1}\right)$ & All Firms $\left(\gamma_{1}\right)$ \\
\hline Entry Rate & -0.00074 & 0.00125 & 0.00051 \\
& $(0.00058)$ & $(0.00100)$ & $(0.00099)$ \\
\hline
\end{tabular}

Panel B: Employment Growth and Survival Analysis

\begin{tabular}{|c|c|c|c|c|}
\hline Dependent Variable & $\begin{array}{c}(1) \\
\text { WSO }\left(\beta_{1}\right)\end{array}$ & $\begin{array}{c}(2) \\
\text { All Firms }\left(\alpha_{1}\right)\end{array}$ & $\begin{array}{c}(3) \\
\text { WSO }\left(\beta_{1}\right)\end{array}$ & $\begin{array}{c}(4) \\
\text { All Firms }\left(\alpha_{1}\right)\end{array}$ \\
\hline \multicolumn{5}{|l|}{ Log Employment } \\
\hline Year 0 & $\begin{array}{l}0.01401^{* * *} \\
(0.00453)\end{array}$ & $\begin{array}{c}-0.01936^{* *} \\
(0.00770)\end{array}$ & & \\
\hline Year 3 & $\begin{array}{l}0.01978^{* * *} \\
(0.00333)\end{array}$ & $\begin{array}{c}-0.02461^{* *} \\
(0.01150)\end{array}$ & $\begin{array}{l}0.00601^{* * *} \\
(0.00201)\end{array}$ & $\begin{array}{r}-0.00957^{*} \\
(0.00512)\end{array}$ \\
\hline Year 5 & $\begin{array}{l}0.01417^{* * *} \\
(0.00437)\end{array}$ & $\begin{array}{c}-0.02969^{* *} \\
(0.01204)\end{array}$ & $\begin{array}{c}0.00395 \\
(0.00347)\end{array}$ & $\begin{array}{c}-0.01601^{* *} \\
(0.00641)\end{array}$ \\
\hline Year 7 & $\begin{array}{c}0.01007^{*} \\
(0.00528)\end{array}$ & $\begin{array}{r}-0.02884^{*} \\
(0.01428)\end{array}$ & $\begin{array}{c}0.00008 \\
(0.00350)\end{array}$ & $\begin{array}{r}-0.01442 \\
(0.00926)\end{array}$ \\
\hline Survival & & & & \\
\hline Survive Year 1 & $\begin{array}{l}0.00140^{* * *} \\
(0.00038)\end{array}$ & $\begin{array}{r}-0.00236^{*} \\
(0.00130)\end{array}$ & $\begin{array}{c}0.00078^{*} \\
(0.00041)\end{array}$ & $\begin{array}{c}-0.00149 \\
(0.00134)\end{array}$ \\
\hline Survive Year 2 & $\begin{array}{c}0.00033 \\
(0.00141)\end{array}$ & $\begin{array}{c}-0.00422^{* *} \\
(0.00181)\end{array}$ & $\begin{array}{c}-0.00048 \\
(0.00130)\end{array}$ & $\begin{array}{c}-0.00309 \\
(0.00184)\end{array}$ \\
\hline Survive Year 3 & $\begin{array}{c}-0.00124 \\
(0.00177)\end{array}$ & $\begin{array}{c}-0.00617^{* * *} \\
(0.00193)\end{array}$ & $\begin{array}{c}-0.00201 \\
(0.00161)\end{array}$ & $\begin{array}{c}-0.00510^{* *} \\
(0.00191)\end{array}$ \\
\hline Log Initial Employment & & & $\mathrm{X}$ & $\mathrm{X}$ \\
\hline
\end{tabular}




\section{B The Full Model}

Table 10: The Life-cycle Impacts of CNC Enforcement: 1991 Starr-Bishara Enforcement Index Showing Coefficients From Full Model, Not Controlling For Initial Size

Panel B: Employment Growth and Survival Analysis

\begin{tabular}{lccccc}
\hline \hline & $\beta_{1}$ & $\beta_{2}$ & $\beta_{3}$ & $\beta_{4}$ & $\beta_{5}$ \\
Dependent Var. & $N L \cdot E n f c \cdot W S O$ & $N L \cdot E n f c$ & $E n f c \cdot W S O$ & $N L \cdot W S O$ & $W S O$ \\
\hline Log Employment & & & & & \\
Year 0 & $0.01132^{* * *}$ & $-0.01356^{* *}$ & $0.01548^{* * *}$ & $0.02747^{* * *}$ & $-0.13558^{* * *}$ \\
& $(0.00191)$ & $(0.00527)$ & $(0.00311)$ & $(0.00663)$ & $(0.00823)$ \\
Year 3 & $0.01439^{* * *}$ & $-0.01312^{*}$ & $0.01570^{* * *}$ & $0.03160^{* * *}$ & $-0.12248^{* * *}$ \\
& $(0.00274)$ & $(0.00710)$ & $(0.00359)$ & $(0.01008)$ & $(0.00965)$ \\
Year 5 & $0.01178^{* * *}$ & $-0.01743^{* *}$ & $0.01746^{* * *}$ & $0.04261^{* * *}$ & $-0.11657^{* * *}$ \\
& $(0.00239)$ & $(0.00751)$ & $(0.00421)$ & $(0.00877)$ & $(0.01021)$ \\
Year 7 & $0.00802^{* *}$ & -0.01477 & $0.02097^{* * *}$ & $0.03749^{* * *}$ & $-0.10400^{* * *}$ \\
& $(0.00378)$ & $(0.00874)$ & $(0.00529)$ & $(0.01160)$ & $(0.01309)$ \\
Survival & & & & \\
Survive Year 1 & $0.00121^{* * *}$ & $-0.00205^{* *}$ & 0.00043 & -0.00035 & $0.05123^{* * *}$ \\
Survive Year 2 & $(0.00036)$ & $(0.00080)$ & $(0.00060)$ & $(0.00134)$ & $(0.00193)$ \\
& $0.00149^{*}$ & $-0.00335^{* * *}$ & 0.00173 & $-0.01724^{* * *}$ & $0.06581^{* * *}$ \\
Survive Year 3 & $(0.00076)$ & $(0.00105)$ & $(0.00155)$ & $(0.00327)$ & $(0.00473)$ \\
& 0.00067 & $-0.00349^{* *}$ & 0.00279 & $-0.02815^{* * *}$ & $0.07170^{* * *}$ \\
\hline \hline F** p<0.01, & $(0.00126)$ & $(0.00143)$ & $(0.00219)$ & $(0.00451)$ & $(0.00652)$ \\
\hline
\end{tabular}

*** $\mathrm{p}<0.01,{ }^{* *} \mathrm{p}<0.05,{ }^{*} \mathrm{p}<0.1$. These results do not control for log of initial employment. This table displays the $\beta$ coefficients from equation (3): $Y_{i j s t}=\beta_{0}+\beta_{1} N L_{i} * E n f c_{s} * W S O_{i j s t}+$ $\beta_{2} N L_{i} * E n f c_{s}+\beta_{3} E n f c_{s} * W S O i j s t+\beta_{4} W S O_{i j s t} * N L_{i}+\beta_{5} W S O_{i j s t}+\lambda_{i t}+\theta_{s}+\phi Z_{i j s t}+v_{i j s t}$ The left-most column represents the dependent variable. WSO stands for within-industry spinout. Robust standard errors are in parentheses, clustered at the state level. All specifications include state fixed effects, and year by 4 digit NAICS fixed effects. Other controls can be found on page 16. 
Table 11: The Life-cycle Impacts of CNC Enforcement: 1991 Starr-Bishara Enforcement Index Showing Coefficients From Full Model, Controlling For Initial Size

Panel B: Employment Growth and Survival Analysis

\begin{tabular}{lccccc}
\hline \hline & $\beta_{1}$ & $\beta_{2}$ & $\beta_{3}$ & $\beta_{4}$ & $\beta_{5}$ \\
Dependent Var. & $N L \cdot E n f c \cdot W S O$ & $N L \cdot E n f c$ & $E n f c \cdot W S O$ & $N L \cdot W S O$ & $W S O$ \\
\hline Log Employment & & & & & \\
Year 0 & $0.01132^{* * *}$ & $-0.01356^{* *}$ & $0.01548^{* * *}$ & $0.02747^{* * *}$ & $-0.13558^{* * *}$ \\
& $(0.00191)$ & $(0.00527)$ & $(0.00311)$ & $(0.00663)$ & $(0.00823)$ \\
Year 3 & $0.00416^{* *}$ & -0.00408 & 0.00178 & $0.01670^{* * *}$ & $0.01393^{* * *}$ \\
& $(0.00163)$ & $(0.00296)$ & $(0.00168)$ & $(0.00489)$ & $(0.00446)$ \\
Year 5 & 0.00219 & -0.00611 & $0.00352^{*}$ & $0.02382^{* * *}$ & $0.02254^{* * *}$ \\
& $(0.00201)$ & $(0.00433)$ & $(0.00173)$ & $(0.00645)$ & $(0.00538)$ \\
Year 7 & -0.00203 & -0.00285 & $0.00968^{* * *}$ & $0.02384^{* * *}$ & $0.03104^{* * *}$ \\
& $(0.00244)$ & $(0.00580)$ & $(0.00283)$ & $(0.00768)$ & $(0.00787)$ \\
Survival & & & & \\
Survive Year 1 & $0.00070^{*}$ & $-0.00144^{*}$ & -0.00026 & -0.00159 & $0.05731^{* * *}$ \\
Survive Year 2 & $(0.00038)$ & $(0.00081)$ & $(0.00051)$ & $(0.00137)$ & $(0.00175)$ \\
& 0.00083 & $-0.00257^{* *}$ & 0.00083 & $-0.01883^{* * *}$ & $0.07368^{* * *}$ \\
Survive Year 3 & $(0.00074)$ & $(0.00114)$ & $(0.00146)$ & $(0.00341)$ & $(0.00464)$ \\
& 0.00005 & $-0.00275^{*}$ & 0.00194 & $-0.02966^{* * *}$ & $0.07916^{* * *}$ \\
\hline \hline E** & $(0.00122)$ & $(0.00155)$ & $(0.00209)$ & $(0.00457)$ & $(0.00634)$ \\
\hline
\end{tabular}

${ }^{* * *} \mathrm{p}<0.01,{ }^{* *} \mathrm{p}<0.05,{ }^{*} \mathrm{p}<0.1$. These results do control for $\log$ of initial employment. This table displays the $\beta$ coefficients from equation (3): $Y_{i j s t}=\beta_{0}+\beta_{1} N L_{i} * E n f c_{s} * W S O_{i j s t}+$ $\beta_{2} N L_{i} * E n f c_{s}+\beta_{3} E n f c_{s} * W S O i j s t+\beta_{4} W S O_{i j s t} * N L_{i}+\beta_{5} W S O_{i j s t}+\lambda_{i t}+\theta_{s}+\phi Z_{i j s t}+v_{i j s t}$ The left-most column represents the dependent variable. WSO stands for within-industry spinout. Robust standard errors are in parentheses, clustered at the state level. All specifications include state fixed effects, and year by 4 digit NAICS fixed effects. Other controls can be found on page 16. 